\title{
Despre desfacerea proprietăților din Moldova după pacea de la București (1812). Cîteva adăugiri ${ }^{\dagger}$
}

\author{
Petronel Zahariuc* \\ Facultatea de Istorie, Universitatea „Alexandru Ioan Cuza”, Bd. Carol I 11, 700506 Iaşi, România
}

\section{Despre articol}

Istoric:

Primit 8 septembrie 2018

Acceptat 13 septembrie 2018

Publicat 7 mai 2019

\section{Cuvinte-cheie:}

Moldova

Basarabia

pacea de la București

1812

sate

tîrguri

\begin{abstract}
Rezumat
După ocuparea Moldovei dintre Prut și Nistru, Imperiul Rus a impus, prin pacea de la București, ca, în termen de 18 luni, proprietarii de moșii să-şi aleagă partea de țară în care vor locui. Pentru o vreme, românii au crezut că armata rusă se va retrage, așa cum a făcut și altă dată, astfel că au amînat luarea unei decizii pînă în toamna anului 1813, atunci cînd au trebuit să se „desfacă” de moșiile din stînga sau din dreapta Prutului. Cei mai mulți dintre marii proprietari au ales să rămînă în Moldova de sub stăpînire otomană, de aceea, poporținal, cea mai mare parte dintre moșiile vîndute au fost din partea de țară ocupată de Imperiul rus. Modul cum s-a realizat acest proces a fost reconstituit de Alexandru Lapedatu (1916), iar prezentul articol aduce o serie de adăugiri și lămuriri, precum și o listă, inedită și nefolosită în istoriografia românească, cu 387 de sate și părți de sate, din Moldova din stînga Prutului, vîndute sau schimbate în ultimele două luni ale anului 1813 și în primele zile ale anului 1814. Totodată, din acest articol se poate observa, la nivel general, felul în care separarea proprietăților și a familiilor a dus la ruperea Moldovei, însă, totodată, în plan secund, acest noian de nume de așezări și de stăpîni va putea fi folosit, cîndva, la realizarea unui dicționar istoric şi toponimic al localităților din stînga Prutului, după modelul aceluia alcătuit pentru localitățile din dreapta Prutului de colectivul de toponimie de la Institutul de Filologie Română „A. Philippide”, coordonat de profesorul Dragoș, Moldovanu.
\end{abstract}

\section{Introducere}

Aruncînd o privire peste bibliografia istorică a Basarabiei am observat că în ultimii ani s-a vorbit mult despre multe dintre aspectele de dinainte, din timpul și de după anul 1812, privitoare la Basarabia, la Moldova întreagă și la întreg Răsăritul Europei. Această mică contribuție nu are nici pe departe orizonturi atît de largi, ci se dorește a fi o mică încercare de a vedea în ce fel s-au rupt ori s-au lipit boierii, răzeșii şi călugării de moșiile, de pămîntul lor, atunci cînd pămîntul țării s-a desfăcut. Pămîntul lor, hotarele satelor lor, constituiau pentru ei singura realitate, în vreme ce hotarul cel mare al țării îl vedeau greu, pe de o parte din pricina unor conducători nevrednici, recrutați dintre ei sau dintre străini, pe de altă parte pentru că nici spiritul vremii încă nu le permitea să-l vadă—abia copiii și nepoții lor îl vor vedea din ce în ce mai bine, iar cînd îl vor vedea și îl vor înțelege, vor plînge. Oare așa să fie și astăzi?

Mai demult, nu de azi, cînd s-au împlinit și au trecut două veacuri de la aşezarea celui dintîi hotar de-a lungul Prutului, rupînd moșiile și ce mai rămăsese din moșia țării în două, ci mai demult, cu cîțiva ani după ce am înțeles că Prutul și-ar putea pierde faima rea, aceea de hotar între români, am început să adun, de prin diferite arhive din dreapta rîului, documente și alte relatări mărunte, din care doream să încheg chipul în care au priceput românii ce s-a întîmplat cu ei și cu țara lor la 1812. Bineînțeles că nu numai din lucruri mărunte se poate încropi o imagine, pentru că de cele mai multe ori viaţa istorică este în altă parte, pentru a parafraza titlul unui celebru roman al lui Milan Kundera, adică în fapte și locuri istorice de

${ }^{\dagger}$ Acest studiu face parte dintre rezultatele proiectului de cercetare: UEFISCDI, PN-III-P4-ID-PCE-2016-0557.

*Adresă de corespondență: zahariuc@uaic.ro. 
anvergură: războaie și capitale, eroi și tratate de pace, fapte de vitejie și josnice trădări. Toate acestea s-au amestecat la 1812 și despre toate s-a scris, și bine și rău, și se va mai scrie multă vreme de acum înainte. Și despre boieri și moșiile lor s-a scris, destul de puțin, dar bine, mai ales cu prilejul comemorării unui veac de la peierderea Basarabiei (Iorga, 1912a; Lapedatu, 1916), în vreme ce despre mănăstiri și moșiile lor s-a scris foarte puțin. Puținătatea acestor studii decurge atît din însemnătatea relativ redusă a subiectului, cît și din lipsa unor cercetări sistematice de arhivă, care a dus la lipsa unor colecții tematice de documente interne, care să cuprindă anul 1812 şi anii următori ${ }^{1}$. La acestea se adaugă injoncțiunea brutală a politicului în cercetarea istorică, întîmplată la Chișinău, la Iași și la București după cel de-Al Doilea Război Mondial. Pe lîngă unele documente publicate de istorici din perioada interbelică (Aurel Sava, Constantin Tomescu, Leon Boga, Ștefan Berechet, Gheorghe Ghibănescu și alții), pe ici, pe colo, în istoriile unor orașe și sate sau în istoriile unor familii s-au strecurat și cîteva documente, care dau seamă de felul în care s-au desprins stăpînii de stăpînirile lor, atît în intervalul 1812-1814, cît și în anii care au urmat.

După schimbările radicale din Răsăritul Europei, întîmplate la sfirsșitul anilor '80 din secolul trecut, și cercetările asupra momentului 1812 au răsărit și au crescut cu putere, iar viața de zi cu zi a oamenilor nu avea cum să scape ochiului atent al istoricului. Istoric care, de data aceasta și în acest domeniu, circumscris cercetării obositoare de arhivă, aparține cercurilor academice și universitare din Republica Moldova și mai puțin, sau deloc, mediului științific din România, preocupat mai ales de reliefarea direcțiilor mari ale vieții istorice românești, una dintre ele fiind istoria generală a spațiului românesc dintre Prut și Nistru și chiar puțin mai încolo. Dintre istoricii din Basarabia, atașaţi cercetării începuturilor istorice a acestei părți de țară românească, devenită provincie rusească, îi amintesc pe Dinu Poștarencu (2006) și, mai ales, pe Valentin Tomuleț (2007; cu bibliografia lucrărilor autorului), un atent și valoros istoric al vieții sociale din Basarabia primelor decenii de după anexare, curgător dintr-un neam vechi de boiernași moldoveni, pe care nu ezită, atingînd culmea imparțialității istorice, să-i veștejească pentru atitudinea, nu întotdeauna prietenoasă, faţă de țăranii muncitori pe sfoară lor de moșie (Tomuleț, 2007, p. 159-178)2.

\section{Desfacerea proprietăţilor din Moldova din stînga și din dreapta Prutului}

Pentru anii 1812-1814, relația dintre boieri și moșiile lor a fost guvernată de articolul VII al Păcii de la București, prin care se dispunea ca supușii otomani (moldoveni), aflați la declararea războiului în Basarabia sau stabiliți acolo în timpul ostilităților, să se poată retrage și așeza, dacă vor dori, dincoace de Prut, liberi find a-și desface bunurile și a emigra cu tot ceea ce vor voi a lua, în termen de 18 luni de la ratificarea tratatului. La fel, boierii născuți în stînga Prutului, dar rezidînd în alte părți ale Imperiului Otoman, puteau să rămînă unde se aflau, rupîndu-se de proprietățile lor basarabene sau puteau să se întoarcă acasă, după ce îşi vindeau averea din dreapta Prutului și a se întoarce cu sumele dobîndite astfel, de cele mai multe ori mici, alteori mari (Manuc-bey, poate fi un exemplu), în Chișinău sau în alte locuri pentru a începe o nouă viață sub noul stăpînitor, creștin ortodox de această dată (ADIRR, p. 299). Această dispoziție era menită să curme legăturile politice și economice dintre cele două părți ale Moldovei situate pe cursul mijlociu și inferior al Prutului și pare inspirată, dacă n-am ști că toate imperiile adoptă această măsură cînd descalecă pe malul unui nou rîu, din măsurile adoptate în cea de-a treia parte de țară, de pe cursul superior al Prutului, ruptă cu o generație mai înainte din trupul țării, în urma unui concurs asemănător de împrejurări, în care toate ingredientele diplomației, urîte pentru cei învinși și binecuvîntate pentru învingători, s-au făcut din plin simțite. Termenul („protezmie”) foarte scurt pentru opțiune, un an și jumătate (pînă la 2 ianuarie 1814), „echivala cu o expropriere” (Iorga, 1938, p. 204), în condițiile în care erau o mulțime de oameni și o mulțime de moșii trebuiau să-și definească statutul.

Pentru a nu lăsa timp unora, puțini ce-i drept, să facă legătura dintre hotarul moșiei lor și hotarul țării, între vînzarea casei părintești și pierderea țării, rușii, prin generalul Harting, au ascuns prevederea de

\footnotetext{
${ }^{1}$ În ultima vreme s-au publicat, și chiar republicat, multe documente din vremea ocupației rusești (1806-1812): Doc. Mold. (2012); Doc. T. Mold. (2017).

${ }^{2}$ Pentru conflictul dintre locuitorii tîrgului Lăpuşna și boierul Iordache Tomuleț, vezi și Sava (1935a, 1935b).
} 
la punctul VII. Ginere de boier moldovean (Bezviconi, 1936, p. 16-109); generalul rus, sau altcineva din suita sa, nu au putut tăinui prea mult acest important punct, care atingea una dintre răspîntiile importante ale drumului, încă încețoșat, ce ducea spre conștiința de grup etnic și religios distinct și spre patriotism. Astfel, apoape imediat, o mare deputăție, avîndu-i în frunte pe doi dintre boierii mari ai unei țări cu oameni politici mici, marii logofeți Constantin Balș și Costache Ghica, a plecat la București spre a obține ușurarea sarcinilor de război și spre a trata chestiunea moșiilor de peste Prut, căutînd să obțină pentru proprietari măcar drepturile pe care le avuseseră după ce se pierduse Bucovina (Rosetti, 1909, p. 37-38). Cred că pentru mulți dintre marii boieri, incomensurabila avere la care ajunsese unul dintre ei, Iordache Rosetti Roznovanu, tocmai în urma nemaipomenitei afaceri cu schimburile de moșii „austriece și turcești”, cum erau numite, constituia un reper, iar conjunctura în care o obținuse se putea repeta. Delegația moldovenească nu a isprăvit nimic în acest din urmă punct, în vreme ce pentru cel dintîi rușii s-au milostivit și au mai redus din contribuțiile, în bani și în natură, pe care le aruncaseră peste Moldova.

Văzînd că noul stăpîn este surd, chiar dacă în biserici se psalmodiau aceleași cîntări, uneori cu aceleași cuvinte, boierii s-au împăcat cu soarta și au mai încercat doar să-i aducă aminte vechiului stăpîn, Imperiul Otoman, ajuns bicisnic și nepăsător, prin intermediul credincioasei și nevolnicei slugi trimise ca „bey”, cu pretenții de domn, Scarlat Calimachi, că hrana lor și a capitalei restului de Moldovă, Iașiii, nu mai vine de peste Prut, iar foametea amenința să intre pe ulițele orașului (Iorga, 1912b, p. 157-158). Măsurile economice dure adoptate de administrația rusească în stînga Prutului au avut în primul rînd un scop politic, și anume deturnarea atenției boierimii moldovene dinspre problemele grave și de durată ale țării, spre probleme de mică importanță privitoare la asigurarea vieții de zi cu zi. În acest context, și aplicarea punctului VII al tratatului de pace devenea presantă, pentru că situația moșiilor de peste Prut se înrăutățea continuu. Marii stăpîni de moșii, care rezidau la Iași, trebuiau să iasă din greaua dilemă, și, în primul rînd, să aleagă de care parte a rîului vor trăi, iar în al doilea rînd, la care moșii și conace vor renunța. Totuși, chiar dacă prevederile tratatului s-au dovedit implacabile, ele nu erau aşa pentru contemporani, care mai sperau într-o întorsătură favorabilă a stării de fapt, într-o ieșire din nenorocire, care să ducă la reîntregirea țării și la păstrarea intactă a patrimoniului familial. Zadarnică nădejde, chiar pentru contemporani, care aveau aproape exemplul Bucovinei, al cărei nume învățaseră deja să-l rostească.

Speranța şi zvonurile care veneau dinspre campania lui Napoleon în Rusia au îndepărtat momentul opțiunii (Casso, 1940; Goșu, 2008), astfel că vreme de cîteva luni, pînă spre sfîrşitul anului 1812, doar cîteva moșii fuseseră vîndute sau schimbate. Mai mult, unele dintre ele au fost aparent înstrăinate, aşa cum mărturisește Catinca Ghica, după schimbul făcut cu socrul ei, vistiernicul Iordache Rosetti, căruia i-a dat moşiile de zestre de peste Prut și a primit un număr de moșii ale acestuia „din partea aceasta a Prutului, de la ținuturile Neamț, Bacău, Putna, Botoșani, Hîrlău, Vaslui și casile din Iași și vii”. Și, iată, ce a spus jupîneasa: „s-au făcut de mini această adevărată încredințare mărturisitoare că acest schimbu nu are nici o ființă, nici putere, fiind numai prin iconomii, și scrisorile ce mi-au dat dumisale vistiernicul, socrul mieu, de schimbu, va fi purure fără lucrare, ca o hîrtie albă” (ANI, Doc., 143/70; 12 noiembrie 1812) 3 $^{3}$ În acelaşi timp, protipendada s-a întrecut în redactarea de anaforale, menite a îndelunga termenul fixat pentru opțiunea traiului în viitor, în care s-au plîns de dificultatea găsirii unor soluții profitabile pentru înstrăinarea moșiilor, precum și de tristețea desfacerii familiilor în două ramuri, de-a dreapta și de-a stînga Prutului: „socotim a ne lipsi de pămîntul strămoșesc, a împărți averea și a ne despărți fiii de părinți, frați şi alte rudenii, trecînd unii la acele de peste Prut moșii, iar alții rămînînd la aceste de aice” (Lapedatu, 1916, p. 8). Pe lîngă anaforale, beneficiind și de experiența comitetului instituit de ruși, la $1808^{4}$, pentru cercetarea actelor de revendicare a proprietăților moldovenești acaparate de turci la constituirea raialei Hotinului (1715), marii boieri au înființat un „Comitet al desfacerii moșiilor de peste Prut” (Iorga, 1995,

\footnotetext{
${ }^{3}$ Un alt zapis de vînzare, făcut cu ,iconomie”, este cel prin care căminarul Anastase Scorțăscu ar fi vîndut căminarului Zamfirache niște stînjeni din moșia Măgureli, la ținutul Iași, pentru care, la 29 decembrie 1813, cumpărătorul recunoaște că „nici i-a cumpărat el, nici a dat banii pe ei” (BAR, Doc. ist., CXXI/199).

${ }^{4} \mathrm{O}$ parte dintre actele rezultate în urma activității acestei comisii se păstrează în arhivele de la Iaşi, iar cîteva dintre ele au fost folosite de colegul Gumenâi (2002).
} 
p. 289), cu însărcinarea de a cerceta și aproba actele de vînzare și de schimb ce se vor încheia și de a judeca litigiile ce ar urma să apară în urma unor asemenea afaceri. De la acest Comitet, actele mergeau la Divanul țării, apoi, spre autentificare, la Consulatul rusesc din Iași, și, în sfîrșit, la Departamentul I al Basarabiei, de la care proprietarii obțineau documente de veșnică stăpînire asupra bunurilor cumpărate sau schimbate.

Cu toată această aparentă organizare, zăpăceala era cuvîntul care caracteriza cel mai bine situația Moldovei, iar această stare de spirit a fost cel mai fidel înfățișată de Manolachi Drăghici, în cuvinte des pomenite de la momentul scrierii lor pînă astăzi, nefiind de prisos reluarea lor şi aici: „locuitorii moldoveni multă vreme au țînut pacè încheiată la București ca nestatornică, așteptînd dintr-o zi pînă în alta înapoierea pămîntului luat de cătră ruși și întregime hotarului țării lor, precum au fost mai dinaite, dar s-au amăgit în ideile ce hrănea, fiindu-le încă și de o mare sminteală în interesile particulare a lor socotința aceasta, pentru că nu s-au grăbit a lua măsuri energice în desfacerea averii nemișcătoare ce avè din a stînga Prutului, pînă sau apropiat vremea protezmiei, cînd umba confuji de nu știè ce să mai facă, unii adecă care luaseră protecțiia rusească o lepăda, alții din acei hotărîți să rămîie în Moldova să făcea sudiți, și tot în taină lucrîndu-se aceste operații spre a nu se declara pînă în ceasul închiderii Prutului, supt ce bandieră rămîn ca să nu greșască. Sosind însă ziua fatală a ecspirării convenției, după tractat, ce trebuiè fieștecare să trăiască unde era să rămîie definitiv, ceasurile acele au fost de plîngeri un timp de neuitat, pentru că poporul cu cîrdul, ca turmile de oi, încinsesă toată marginea Prutului, de la un capăt pînă la altul, mergînd și viind de prin sate și de prin tîrguri săptămîni închiete, cu luarea de ziua bună de la părinți, de la frați și de la rudenii cu care crescusă și viețuisă dinpreună pînă în vremea aceea cînd să dispărță unii de alții pentru totdeauna” (Drăghici, 2017, p. 202-203).

Poporenii erau, într-adevăr, dezorientați, mulți dintre ei alegînd să treacă la dreapta Prutului, însă conducătorii lor nu au lăsat rezolvarea stării lor patrimoniale pentru ultima clipă. Astfel, după eșecul tentativei, de la începtul lunii noiembrie 1813, de a obține amînarea termenului fixat prin „hotărîrea svintelor tractaturi închiete în București, la anul 1812, între preputernicile împărății a Curții Rosîei și a Porții Othomanicești” " Mitropolia Moldovei și Sucevei, mănăstirile și boierii au crescut ritmul vînzărilor și schimburilor de moșii situate de o parte și de alta a Prutului. Pentru că puțini dintre marii proprietari au ales să trăiască în stînga Prutului, iar autoritățile țariste au înființat o nouă structură eclesiastică în teritoriul ocupat, majoritatea tranzacțiilor imobiliare au avut drept conținut tîrguri, sate și părți de sate din ținuturile răpite. Desigur că există și tranzacții inverse, însă mult mai modeste, în care partea care vinde sau schimbă ceva, mai ales din „boierimea măruntă” (Iorga, 1938, p. 205), a fost nevoită să aleagă a trăi sub oblăduirea țarului rus. Foarte puțini dintre boierii mici, care își aveau casele la moșiile din stînga Prutului, mai aveau alte bucăţi de moșie în dreapta rîului ${ }^{6}$. Mai degrabă găsim, ici-colo, cîte o fiică de boier, măritată cu vreun ofițer din armata rusă, care s-a așezat dincolo de Prut, la Chișinău sau mai departe în Rusia, și și-a vîndut zestrea părintească

În schimb, acte de vînzare-cumpărare și de schimb ale persoanelor particulare și ale instituțiilor, care

${ }^{5}$ Formulare din actul de vinzare, cu data de 30 decembrie 1813 (ANI, Doc., 215/8). În alte documente, sintagma „svintele tractaturi” este înlocuită cu ,înaltele tractaturi” (vezi, spre exemplu, actul din 16 decembrie 1813; Lapedatu, 1916, p. 32, nr. 12).

${ }^{6}$ Printre ei s-a aflat și Andrei Milu, care, alegînd să se stabilească în stînga Prutului, i-a vîndut spătarului Constantin Catargi, la 28 decembrie 1813, moșia Muncel, din ținutul Roman (ANI, 0, 407/74).

${ }^{7}$ La 26 iunie 1812, Caterina, fiica răposatului boier Grigoraș Bașotă fost mare spătar, soția polcovnicului Alexei Bolgovscoi, „hotărînd de a mă duce de aice cu lăcuința în Rosiia, înpreună cu soțul mieu”, a vîndut 20 de sălașe de țigani (70 de suflete, în total), unei tovărășii formate din spătarul Alecu Greceanul, paharnicul Tudurachi Ciure și sulgerul Ianachi Adam, cu 15.459 lei. Interesant este faptul că ocupațiile țiganilor arată în seama cui cădeau meseriile pe o moșie boierească, deoarece printre aceștia găsim: un croitor, un curelar, doi ciubotari, doi vizitii, un fierar, un cojocar, un pitar, trei scripcari și un bucătar (ANI, Doc., 344/73). La 30 septembrie 1812, Caterina a vîndut, din același motiv, și moșia Vlădeni, din ținutul Hîrlău, cu 30 de gospodari, biserică, cîrciumă și loc de hrană, lui Iordache Catargiu fost mare spătar, pentru 60.050 lei (Lapedatu, 1916, p. 18-20, nr. 1, 2). Pentru viața scandaloasă a Ecaterinei, care a fost, prinre altele, și amanta poetului Pușkin, vezi notița lui Mihai Dim. Sturdza (2004, p. 378). Apoi, la 1 ianuarie 1814, maiorul Costandin Șainovici și soția sa, Despina, fiica lui Tănase căpitan de dărăbani, vînd postelnicului Mihalache Mavrogheni o parte din moșia de zestre a Despinei, Oroftiana, din ținutul Herța, cu 6.000 de lei (ANI, Doc., 462/51). Maiorul Șainovici și-a făcut casă în Chișinău (Sava, 1933, p. 678-679). 
și-au păstrat reședințele acolo unde le era locul, sunt mult mai multe, unele publicate ${ }^{8}$, altele nu, unele descoperite, altele nu, fiind îngrămădite în cele două luni de la sfîrșitul anului 1813. Unul dintre primele acte de anvergură, de schimb și de vînzare, a fost făcut de mitropolitul Veniamin Costachi, la 18 noiembrie 1813, și de Alexandru Anastase fost mare serdar, prin care cel dintîi a dat cîteva moșii ale Mitropoliei și o moșie a mănăstirii Pîngărați de dincolo de Prut și a primit moșiile de dincoace de Prut ale serdarului, împreună cu suma de 62.000 lei (Lapedatu, 1916, p. 26-27, nr. 7) . De moşiile de dincolo de Prut sau „desfăcut” și o parte dintre mănăstirile pămîntene, în vreme ce toate mănăstirile închinate Locurilor Sfinte, după un moment de derută, cînd s-au precipitat și au început să-și înstrăineze posesiunile (Lapedatu, 1916, p. 26-27, nr. 8; raportul generalului Harting către țar, din 7 decembrie 1813), au fost sfătuite să revină, permițîndu-li-se să și le administreze în continuare (Cazacu, 1992, p. 129). Tratamentul diferențiat acordat mănăstirilor din Moldova rămasă sub stăpînire otomană, mai ales a acelora închinate unor așezăminte din Sudul Dunării, a constituit o nadă aruncată de puterea ortodoxă de la Nord în calea clerului și credincioșilor ortodocși din Moldova și din Balcani, care a dat rezultate doar în cazul celor din urmă (Niţă-Danielescu, 2017, p. 393).

Persoanele particulare, însă, care au fost clar definite în articolul VII al tratatului de la București, au fost obligate să se supună, astfel că au trebuit să găsească, într-un termen înnebunitor de scurt, la care se mai adăuga și ameninţarea ciumei ${ }^{10}$, căile pentru a salva, prin acte de vînzare sau de schimb, adevărate sau disimulate, ceva din prețul corect al averilor imobiliare din ținuturile de peste Prut. Astfel, din noiembrie 1813 pînă la începutul lui ianuarie 1814, de-a dreapta și de-a stînga Prutului a fost un „tîrg imobiliar” generalizat, care a avut de toate: cîștigători și pierdanți, prețuri bune și, mai ales, chilipiruri, sărăciți și îmbogățiți, lacrimi și chiote de bucurie, ce sunt succint și sec adunate în lista sau „izvodul de moşiile ce s-au cumpărat în oblaste Basarabiei, cu arătari numelor satelor și în ce ținut anumi să află, cum și numele vînzătorilor și a cumpărătorilor”, din februarie 1814, pe care îl publicăm acum (vezi Anexa).

Lista, așa cum s-a păstrat, cuprinde 387 de sate și părți de sate, răspîndite în toate ținuturile Moldovei din stînga Prutului. Din încheierea abruptă a „caietului” de șase file păstrat, pare să rezulte că lista a mai avut o filă sau poate două, între timp pierdute, cu care numărul aşezărilor ar spori cu cîteva zeci. Faptul că lista ar fi putut avea cîteva file în plus este dovedit și de o serie de documente inedite, care cuprind sate ce nu sunt printre cele din izvodul păstrat. Oricum ar fi, lista păstrată cuprinde peste jumătate din satele din ținuturile din Basarabia, dacă luăm drept reper numărul de 685 de sate și 17 tîrguri, oferit de Ion Nistor $(1991, \text { p. 179 })^{11}$. În afara listei au rămas, în cazul în care stăpînirea lor nu era îmbucătățită, satele stăpînite de boierii care s-au stabilit în Basarabia, satele răzășești și satele mănăstirești. Informaţia, cuprinsă în acest document sintetic, dă seamă și despre stăpînii satelor și părților de sate în 1812, chiar dacă, în unele cazuri, se poate ca între momentul ocupației şi momentul vînzării sau schimbului, proprietarul să se fi schimbat, mai ales prin balansarea dreptului de proprietate între ramurile aceleași familii. Și, totodată, documentul nu dă seamă despre sumele de bani cu care s-au vîndut aceste sate, pe de o parte pentru că părtașii nu au fost prea dornici să le facă știute, iar pe de altă parte pentru că multe dintre sumele declarate erau încărcate cu tainice povești.

Fără vreo poveste, alta decît tragica moarte a fraților Moruzi (Iorga, 1910; Goșu, 1998), a fost schimbul din 16 noiembrie 1813, prin care comisul Ioan Balș a luat de la Constantin Alexandru Moruzi și de la moștenitorii „voievozilor Dimitrie și Panaitache”, reprezentați de epitropii: Costache Ghica logofăt,

\footnotetext{
${ }^{8}$ Grupajul cel mai mare de documente a fost publicat de Lapedatu (28 de acte, din intervalul 29 septembrie 1812 - 23 mai 1814; 1916, p. 15-48). De asemenea, un interesant act, prin care spătarul Ioniță Bașotă, stabilit în Basarabia, strînge moșii, prin schimb și cumpărare, de la vistiernicul Grigoraș Sturza, de la banul Ioan Vîrnav și de la Dimitrie Bogdan (cu acesta s-a înțeles pentru suma de 292.000 de lei), a fost publicat de Georgescu-Vrancea (1934, p. 175-180).

${ }^{9}$ Pentru actul original, vezi ANI, 320/79; vezi și cele două documente din decembrie 1813, prin care sunt lămurite unele detalii ale tranzacției (Lapedatu, 1916, p. 27-29, nr. 9-10).

${ }^{10}$ BAR, Doc. ist., CXIV/151 (la 6 februarie 1814, Scarlat vodă Calimachi se îngrijea de așezarea unei „linii de străji, din Siret și pînă la munte despre Vrancea, spre a fi întru pază de boala ciumii”).

${ }^{11} \mathrm{Cu}$ o generație înainte, fără satele din raiaua Hotin, Moldova ținuturile din stînga Prutului numărau în jur de 500 de sate, potrivit recensămintelor rusești din 1772-1773 și 1774 și „,condicii liuzilor” din 1803 (Dmitriev, 1973, p. 46-47, 64).
} 
Sandul Sturza hatman și Răducanu Roset hatman, moșia întreagă, Hotărniceni ${ }^{12}$, și moșia vecină, Molești (vezi și izvodul de mai jos), dîndu-le în schimb moșiile: Pașcani, din ținutul Sucevei, Ezăreni și Giulești, numite Hodora, din ținutul Hîrlău, și Conțești, în hotar cu moșia Pașcani (această moșie era „luată de veci”, cu 250 de lei anual, de la mănăstirea Probota), împreună cu suma de 40.000 de lei. Schimbul s-a făcut, arată comisul Balş, cu voia patriarhului ecumenic și în urma ,înaltei porunci de a se desface, spre îndestulare creditorilor ce au să ia de la casa răposaților voevozi Dimitrie și Panaitache, întocma după hotărîre sfintelor trahtaturi şi înoire a mai marilor înalte poronci, voind a ne desface și o parte și alta de moșiile din străine stăpîniri” (ANI, Doc., 340/48) ${ }^{13}$. Schimbul s-a întîmplat cu adevărat, pentru că la 22 iulie 1814, epitropii au scos la mezat, cu învoirea domnului, moșiile din dreapta Prutului (ANi, Doc., 143/75).

Cu poveste, însă, au fost extraordinarele, la propriu și la figurat, vînzări de moșii, întîmplate într-o singură zi, 21 decembrie 1813, care îl au drept protagonist pe comisul Alexandru Panaite. Dintre actele întocmite atunci, după un formular de cancelarie asemănător, am descoperit cinci, nefiind deloc exclus să mai fie și altele. Motivația superioară a acțiunii de vînzare-cumpărare este clar exprimată: „după poruncile ce sînt date de obștie cu puterea legăturii trahtaturilor pentru toți acei ce au moșii și acareturi, adică în stînga Prutului, acei ce sînt cu lăcuința în dreapta Prutului, și în dreapta Prutului, acei cei sînt cu lăcuința în stînga Prutului, ca să să pue la cale și să să desfacă pînă la eșirea protizmii, ce are cursul său pînă la 2 ghenarie, anul 1814, prin oricarele chip vor pute spre împlinirea poroncii”. Iar motivul imediat și dătător de seamă asupra chinului vînzătorilor de a-şi găsi cumpărători este aidoma formulat: „negăsind chip cu schimb deopotrivă și de mulțămire a le da și a lua în dreapta Prutului”.

Și iată, știind cumpărătorul, care sunt vînzătorii, care sunt satele și care sunt sumele: Iordache Roset fost mare vistier vinde tîrgul Briceni și moșiile Hrubna și Hrimancăuți, toate într-un hotar, la ținutul Hotin, precum și tîrgul Soroca și moșia Rublenița, într-un hotar, la ținutul Soroca, cu 550.000 de lei (ANI, Doc., 341/11 și 341/5) ${ }^{14}$; Neculai Roset fost mare spătar vinde moșiile: Rădești, Șcheia, jumătate de Mălești, jumătate Tăisăni, trei părți din Trielești, „toate într-un hotar, supt nume de Sculeni”, la ținutul Iași, împreună „cu carantina din stînga Prutului”, în preț de 400.000 de lei (ANI, Doc., 341/10 și 341/4); spătăreasa Catinca Ghica vinde moșiile: Medvica sau tîrgul Lipcani, Crușăuți, Cîșla Zamgiului, Răsteul, Hlinaia și Coşuleni, toate într-un hotar, la ținutul Hotin, jumătate din Şofricani și jumătate din Paşuțeni, într-un hotar, la ținutul Iași, Zăhăicani, Stolniceni, Stîngăceni și jumătate din Hiliuți, într-un hotar, la ținutul Iași, tîrgul Rezina și moșia Tohnoaia, într-un hotar, la ținutul Orhei, Sărăteni, Avrămeni, Coromîslești, părți din Coropceni, părți din Hîjdăeni, părți din Ciocîlteni, într-un hotar, ținutul Orhei, Perieni, Măzărești, jumătate din Roșcani, într-un hotar, la ținutul Orhei, cu prețul de 909.000 lei (ANI, Doc., $341 / 9$ și 341/7); vistierniceasa Anica Bogdan, soția vistiernicului Iordache Roset, vinde moșia Sărata, din ținutul Iași, cu 80.000 de lei (ANi, Doc., 341/8 și 341/6). Prețul total, 1.939 .000 lei! Tainele acestor contracte se mai luminează, dacă citim clauza cuprinsă în toate, într-o formă mai succintă sau mai dezvoltată. Iat-o, desprinsă din actul de vînzare al spătăresei Catinca Ghica ${ }^{15}$ : „să aibă a mi-i plăti în vade de doizprăzăci ani, fără de nici o dobîndă, ce tot venitul ce va eși de pe moșiile acestea să fie dator a mi-l da mie în preajma dobînzii banilor, scăzînd numai cheltuiala ce să va face cu căutarea moșiilor pe fieștecare an”. Pentru că vînzătorii de mai sus erau rude între ei, comisul Alexandru Panaite a dat, în aceeași zi, un act prin care se recunoaște a fi doar ,vechil și purtător de grijă” a acestor moșii, fără arăta că s-a angajat să și le cumpere cîndva (ANI, Doc., 143/74). Acest lucru dă mărturie despre faptul că, acei 12 ani, prevăzuți în contracte,

\footnotetext{
${ }^{12}$ Moșia Hotărniceni a fost încorporată Moldovei în 1775 de Grigore Alexandru Ghica, care a dăruit-o fiilor săi Dimitrie și Alexandru (Năstase, 1933, p. 318-322).

${ }^{13}$ Comisul Ioan Balș și-a vîndut și el averea din dreapta Prutului, care cuprindea și 74 de sălașe de țigani (371 de suflete). Acestea au fost vîndute, la 18 decembrie 1813, vornicului Dimitrie Bogdan, cu suma de 42.665 de lei (ANI, Doc., 606/34).

${ }^{14}$ Originale, unul cu semnătura cumpărătorului și unul cu semnătura vînzătorului; următoarele trei acte de vînzarecumpărare sunt tot dublete.

${ }^{15}$ Catinca Ghica a fost soția lui Nicolae Roseti-Roznovanu (ANI, Doc., 341/13), de care a divorțat după un răsunător proces; vezi și Rosetti, 1938, p. 121-122).
} 
s-au dorit a fi doar o voltă și o „iconomicoasă schimbare”, pînă la „întruparea țării iarăși într-o stăpînire sau pînă la o prifacire a stăpînirii” (Lapedatu, 1916, p. 12, 23-24, nr. 6) ${ }^{16}$. Apoi, din cîte se pare, aceste acte nu au avut viață lungă ${ }^{17}$, pe de o parte pentru că nu sunt menționate în lista de mai jos, iar pe de altă parte pentru că, încă din primăvara anului 1814, o parte dintre moşii reapar în stăpînirea vînzătorilor.

Un alt cumpărător norocos a fost pitarul Teodosie, care doar cu cîteva zile înainte de expirarea „protezmiei di optsprezăci luni”, a cumpărat, la 30 și 31 decembrie 1813, de la Nastasia Roset, fiica răposatului Neculai Roset logofăt și soția banului Costachi Razu, moșiile ei de zestre: Pripiceni, pe care era satul Dubna, jumătate din Părcanile, jumătate din Ciripcău, în ținutul Soroca, pentru care vînzătoarea a primit învoire de la fratele ei, Iordache Roset vistier, cu 60.000 de lei (ANI, Doc., 215/8), iar de la Safta Costachi, fiica vornicului Costandin Costachi și soția comisului Teodor Sturza, moșiile: Cunice, cu acareturi și cu sat, și o parte din Hăsnășăni, cu heleșteu și moară de piatră pe Cobolta, tot în ținutul Soroca, pentru 80.000 de lei (ANI, Doc., 462/50; Ghibănescu, 1914, p. 353-356), după ce, la 1 decembrie, a cumpărat de la epitropii beizadelei Costachi Moruzi și de la domnița Ralu, fiica lui Alexandru Costandin Mavrocordat, tîrgul Telinești, din ținutul Orhei, cu 90.000 de lei (ANI, Doc., 191/61 ${ }^{18}$; Costăchescu, 1930, p. 35). Aceste vînzări s-au produs cu adevărat, fiind nominalizate în lista de mai jos, iar pitarul Teodosie a intrat în stăpînirea acestor moșii, pe care, prin testamentul din 13 noiembrie 1817, le-a lăsat moștenire copiilor săi (Costăchescu, 1930, p. 145-147) ${ }^{19}$.

În aceleaşi zile, proprietarii de moşii din stînga Prutului, care au rămas să trăiască în dreapta rîului, au căutat soluții ad-hoc pentru rezolvarea situației. Una dintre aceste soluții, folosite pe scară largă, ne este dezvăluită de un act, din 15 februarie 1816, prin care Teodor Balș fost mare vornic, schimbă moșii cu Ioan Străzescu şi soția lui, Maria; vornicul dă trei părți din moșia Trebujăni, de pe Ciuhur, din ținuturile Hotin și Iași, „pe care este lăcuit satul Horodiște”, și ia a patra parte din moșia Ciurești și părți din moșiile Chilieni şi Păcurărești, din ținutul Tutova, care erau de zestre ale Mariei, precum și 12.000 lei. Însă pînă a ajunge aici, Teodor Balș arată următoarele: „deci eu ca un supus al Porţii Othomanicești, după putere svintelor tractaturi, am urmat a mă desfaci de moșiile și părți de moșii, clironomii de la părinții miei și de la alte niamuri a meli, ci am avut în ținutul Hotinului, care anume să arată în țîdula mezatului, și li-am scos la sultan-mezat, pentru care urmîndu-se publicarisîre mezatului și nearătîndu-si nime nici cu o pretenții s-au săvîrșit mezatu asupra supusului împărății Rosîei, dumisali comisul Iancu Balş, precum adiverește în țîdula mezatului ci esti din 1813 dechemvrie 28, și pentru că dumnealui comisul atunce n-au avut banii ca să mi-i plătiască m-am fost alcătuit ca să mi-i plătiască cu vadeli și cu dobîndă în curgire de patru ani”, însă, pentru că vreme de doi ani comisul nu a plătit nimic, ,am fost sîlit a veni însumi aice, la Chișinău, unde spre a nu întra în giudecăți li-am cumpărat moşîile şi părțile de moșii şi li-am luat toate întru a me stăpînire" (ANI, Doc., 210/1).

\section{Concluzii}

Pe lîngă vînzările aparente sau „cu cîntec”, menționate mai sus, au mai fost și altele, care apar în izvodul, pe care îl publicăm acum, deoarece unele dintre moșiile „vîndute” apar în catagrafia ținuturilor 1817 a localităților din Basarabia, tot în proprietatea rezidenților din Moldova din dreapta Prutului (Halippa, $1907)^{20}$. Totuși, avînd în vedere faptul că în această catagrafie numărul proprietarilor cu rezidența în

\footnotetext{
${ }^{16}$ La 28 decembrie 1813, Manolache Radu fost mare serdar i-a dat lui Enăcachi bănariul moșia Lucăceni din stînga Prutului, primind moșia Lucești, din ținutul Tutova, părți din Buhăești și Comănești, din ținutul Vaslui, și 5 pogoane de vie la Odobești, sperînd că „bănarul”, negustor fiind, va găsi o formă de a valorifica cu cîștig moșia din Basarabia (ANI, Doc., 413/54), însă la 1 ianuarie, părțile au făcut un nou act, prin care arată că-și păstrează documentele moșiilor, pentru ca schimbul să poată fi, la cerere, anulat (ANI, Doc., 413/62).

${ }^{17}$ Aceste moșii nu sunt amintite printre stăpînirile comisului Alexandru Panaite (Bezviconi, 1943, p. 57).

${ }^{18}$ Actul, dăruit Arhivelor Naționale din Iași, provine din arhiva istoricului basarabean Paul Gore.

${ }^{19}$ Pentru pitarul Teodosie (Teodosiu), vezi și Bezviconi (1940, p. 145-147).

${ }^{20}$ Acest recensămînt a fost publicat fragmentar și interpretat și de: Tomescu (1927), Porucic (1933), Teodorescu (1935, 1936, 1937, 1938), Mutruc (2003).
} 
Moldova este foarte mare, iar numărul actelor de vînzare-cumpărare și de schimb a moșiilor din Basarabia, începînd cu ianuarie 1814, este foarte mic, s-ar putea ca acest în recensămînt să se fi înregistrat proprietarii de dinainte de valul de vînzări și schimburi din noiembrie-decembrie 1813. O dată cu începutul anului 1814, trepidația „tîrgului imobiliar” s-a potolit, iar procesul de „desfacere” a moșiilor boierești, aflate de o parte și de alta a Prutului a mai produs, vreme de cîțiva ani, doar cîteva acte de căutare a posesiei ${ }^{21}$, de rearanjare a vînzărilor ${ }^{22}$, de compensație acordată boierilor de domnii din Moldova pentru proprietățile pierdute din Basarabia ${ }^{23}$ sau de arendare iluzorie a unor moşii ${ }^{24}$.

Acestea fiind spuse, se poate observa, la nivel general, din documentele de mai sus și din lista de mai jos, felul în care separarea proprietăților şi a familiilor a dus la ruperea țării, însă, totodată, în plan secund, acest noian de nume de așezări și de stăpîni va putea fi folosit, cîndva, la realizarea unui dicționar istoric și toponimic al localităților din stînga Prutului ${ }^{25}$, după modelul aceluia alcătuit pentru localitățile din dreapta Prutului de colectivul de toponimie de la Institutul de Filologie Română „A. Philippide”, coordonat de profesorul Dragoș Moldovanu.

\section{Bibliografie}

\section{A. Surse}

ADIRR = Acte și documente relative la istoria renașterii României, publicate de Ghenadie Petrescu, Dimitrie A. Sturdza și

Dimitrie C. Sturdza, vol. I, București.

ANB, Doc. mold. $=$ Arhivele Naţionale București, Documente moldovenești.

ANI, Doc. = Arhivele Naționale Iași, Documente.

BAR, Doc. ist. = Biblioteca Academiei Române, București, Documente istorice.

Bezviconi, Gh. (1940). Boierimea Moldovei dintre Prut și Nistru, Actele Comisiei pentru cercetarea documentelor nobilimii din Basarabia, la 1821, publicate de Gheorghe G. Bezviconi, vol. I, București.

Bezviconi, Gh. (1943). Boierimea Moldovei dintre Prut și Nistru. Actele Comisiei pentru cercetarea documentelor nobilimii din Basarabia, la 1821, publicate de Gheorghe G. Bezviconi, vol. II, București.

Doc. Mold. = Documente privind istoria Moldovei sub ocupaţia militară rusă (1806-1812), vol. întocmit de A. Agachi, I. Varta, V. Constantinov, L. Svetlicinâi, T. Varta, Chișinău, 2012.

Doc. T,. Mold. = Documente privitoare la istoria Țării Moldovei în perioada războiului ruso-turc (august 1808 - iunie 1809), vol. întocmit de Demir Dragnev, Larisa Svetlicinâi, Teodor Candu, Tudor Ciobanu, București-Brăila, 2017.

Drăghici, M. (2017). Istoria Moldovei pe timp de 500 de ani pînă în zilele noastre. Ediție, introducere și note de Andrei Pippidi, Editura Academiei Române, București.

Ghibănescu, Gh. (1914). Surete și izvoade, vol. IX (Documente basarabene), ed. Gh. Ghibănescu, Iași.

Halipра, I. (1907). Роспись землвладпнія и сословнаго строя населенія Бессарабіи по даннымз переписи 1817 года, în „Труды Бессарабской Губернской Ученой Архивной Комиссии”, III, Chișinău, p. 3-229.

Sava, A.V. (1933). Crîmpeie din viața Basarabiei sub ruși (1812-1830), II, nr. 11, p. 677-692.

Sava, A.V. (1935a). Din istoria problemei agrare în Basarabia. Răzvrătire țărănească în tîrgul Lăpuşnei. Raporturile dintre săteni și proprietarul moșiei după răpirea Basarabiei. Inrăutățirea regimului sub ruși. Lista gospodarilor din Lăpuşna în 1817, în „Arhivele Basarabiei”, VII, nr. 2, p. 145-160.

\footnotetext{
${ }^{21}$ Aceeași jupîneasă, Catinca Ghica, după divorțul de Neculai Roset, căuta la 9 mai 1817, să-și ia în stăpînire moșiile de zestre, aflate în stînga și din dreapta Prutului, de la epitropii: logofătul Dimitrie Sturza și hatmanul Răducanu Roset (ANI, Doc., 479/25 și 143/83).

${ }^{22}$ La 15 mai 1817 mai 15, Costandin Sturza fost mare agă îi vinde lui Gheorghe Potirachi maior moșiile Vlădești și Brițcani, din ținutul Greceni, „clironomie de la părinții lui”, rămase în urma împărțelii cu fratele lui, Ștefan Sturza spatar, cu 110.000 lei, prin vechilul „Ioan Sturza fost mare spatar, supusul a aceștiia împărății a Rosiei” (ANI, Doc., 611/5).

${ }^{23} \mathrm{La} 10$ septembrie 1814, vistierniceasa Zmaragada Balș, care primește de la Scarlat vodă Calimachi 50 de poslușnici, pentru că, ,prin așăzarea hotarului Prutului, cea mai mare parte a moșiei dumisale, Zberoaia, de la ținutul Eșii, care o are de zăstre, au rămas în partea de la stînga a Prutului, iar mai vîrtos oamenii ce-i ave pe dînsa, cu satul, casă și altele au rămas cu totul în partea aceia" (ANI, Doc., 462/59).

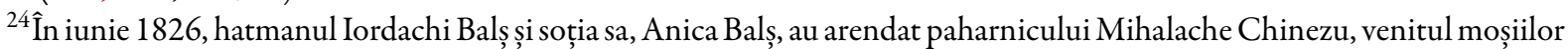
din ținutul Iași, „din oblastia Basarabiei”: Dănuțăni, cu seliștile Oișeni, Băilești, Țuțora Nouă și Țuțora Veche, Vladnicul, cu seliștele sale, și Pîrliții, pe patru ani, cu 3.000 de lei pe an; însă cine poate spune cum și-a onorat arendașul obligațiile asumate prin contract, de vreme ce trăia la Iași! (ANI, Doc., 229/2).

${ }^{25}$ Din cîte știu, dicționarul realizat de la Vladimir Nicu (1991) a rămas singura încercare de acest gen, realizată după căderea comunismului.
} 
Sava, A.V. (1935b). Din istoria problemei agrare în Basarabia. Răzvrătire țărănească în tîrgul Lăpuşnei, în „Arhivele Basarabiei”, VII, nr. 3-4, p. 241-256.

Tomescu C.N. (1927). Catagrafia Basarabiei din 1817. 1. Ținutul Hotinului, Chișinău, 1927, p. 3-49.

\section{B. Lucrări de referință}

Bezviconi, Gh. (1936). Din vremea lui Alexandru Sturdza (1791-1854), în „Din trecutul nostru”, nr. 36-39, p. 1-81.

Casso, L. (1940). Rusia și basinul dunărean, trad. de Șt. Gr. Berechet, Iași.

Cazacu, P. (1992). Moldova dintre Prut și Nistru (1812-1918), Chișinău.

Costăchescu, M. (1930). Satul și tîrgul Telinești din județul Orhei. Schiță istorică, Iași.

Dmitriev, P. G. (1973). Народнонаселение Молдавии (по материалам переписей 1772-1773, 1774 и 1803 22.), Chișinău.

Goșu, A. (1998). Pacea de la București și Moruzeștii, în Național și universal în istoria românilor. Studii oferite prof. dr. Șerban Papacostea cu ocazia împlinirii a 70 de ani, redactori Ovidiu Cristea și Gheorghe Lazăr, București, p. 362-387.

Goșu, A. (2008). Intre Napoleon și Alexandru I. Principatele dunărene la începutul secolului al XIX-lea, București.

Georgescu-Vrancea, C. (1934). Boierimea basarabeană și pacea din București din anul 1812, în „Arhivele Basarabiei”, VI, nr. 2, p. $175-180$.

Gumenâi, I. (2002). Istoria ținutului Hotin de la origini pînă la 1806, Chișinău.

Iorga, N. (1910). Alte lărmuriri despre veacul al XVIII-lea după izvoare apusene. Luarea Basarabiei și Moruzeștii, București.

Iorga, N (1912a). Din ținuturile pierdute. Boieri și răzeși în Bucovina și Basarabia în cele dintîi decenii după anexare, București.

Iorga N. (1912b). Basarabia noastră. Scrisă după 100 de ani de la răpirea ei de către ruşi (Studii și documente cu privire la istoria românilor, vol. XXIV), Vălenii de Munte.

Iorga, N. (1938). Istoria românilor, vol. VIII (Revoluționarii), București.

Iorga, N. (1995). Neamul românesc în Basarabia. Ediție îngrijită, introducere, note și bibliografie de Iordan Datcu, Ed. Fundației Culturale Române, București.

Lapedatu, Al. (1916). Documente și lămuriri istorice cu privire la desfacerea proprietăților moldovene de peste Prut după pierderea Basarabiei (16/28 mai 1812 - 2/14 ianuarie 1814), București.

Mutruc, V., (2003). Cu privire la evoluția proprietății funciare în Basarabia în prima jumătate a secolului al XIX-lea, în In memoriam professoris Mihail Muntean, editori: Valentin Tomuleț, Igor Șarov, Igor Ojog, Aurel Zanoci, Chișinău, p. 114136.

Năstase, Gh.I. (1933), „Hotarul lui Halil Paşa” și „cele 2 Ceasuri”. Schițarea unei probleme de geografie istorică și politică moldovenească, în „Viața Basarabiei”, II, nr. 6, p. 309-322.

Nicu, V. (1991). Localitățile Moldovei în documente și cărți vechi. Îndreptar bibliografic, vol. I-II, Chișinău.

Nistor, I. (1991). Istoria Basarabiei, Chișinău.

Niță-Danielescu, D. (2017). Mănăstirile „închinate” din Moldova în anii războiului ruso-turc (1806-1812), în Relațiile românilor cu Muntele Athos și cu alte Locuri Sfinte (sec. XIV-XX). In honorem Florin Marinescu, editor Petronel Zahariuc, Editura Universității „Alexandru Ioan Cuza”, Iași, 2017, p. 385-393.

Porucic, T. (1933). Regiunile naturale dintre Prut și Nistru, în „Viața Basarabiei”, an II, nr. 3, p. 156-167.

Poștarencu, D. (2006). Anexarea Basarabiei la Imperiul Rus, Chișinău.

Rosetti, R. (1909). Arhiva Senatorilor din Chişinău și ocupația rusească de la 1806 la 1812, III (Amănunte asupra Moldovei de la 1808 la 1812), București.

Rosetti, R. (1938). Familia Rosetti, I (Coborîtorii moldoveni ai lui Lascaris Rousaitos), București.

Sturdza, M.D. (2004). Familiile boierești din Moldova și Țara Românească. Enciclopedie istorică, genealogică și biografică, vol. I, coordonator și coautor Mihai Dim. Sturdza, București.

Teodorescu, C. (1935). Moldova și Basarabia 1807-1817, în „Arhivele Basarabiei”, VII, nr. 1, p. 45-73.

Teodorescu, C. (1936). Moldova şi Basarabia în 1807-1817. Averea mişcătoare și poporația jud. Hotin, în „Arhivele Basarabiei”, VIII, nr. 4, p. 266-275.

Teodorescu, C. (1937). Moldova și Basarabia 1807-1817. Averea nemişcătoare şi poporația județului Soroca în 1817, în „Arhivele Basarabiei”, IX, nr. 1-4, p. 102-111;

Teodorescu, C. (1938). Moldova și Basarabia 1807-1817. Averea nemișcătoare și poporația județului Soroca, în „Arhivele Basarabiei", X, nr. 1-4, p. 129-138.

Tomuleț, V. (2007). Cronica protestelor și revendicărilor populației din Barabia (anii 1812-1828), Chișinău, 2007.

Tomuleț, V. (2014). Basarabia în epoca modernă (1812-1918). Instituții, regulamente, termeni, ediția a II-a, revăzută și adăugită, Chișinău. 


\section{Anexa A. ANB, Doc. mold., XIII/12. Original, hîrtie, 6 file.}

Izvod de moșiile ce s-au cumpărat în oblaste Basarabiei, cu arătari numele satelor și în ce ținut anumi să află, cum și numele vînzătorilor și a cumpărătorilor. 1814 fevruarie

\begin{tabular}{|c|c|c|c|c|}
\hline No. & Numele moșiilor & & Cini anumi au vîndut & Cini anumi au cumpărat \\
\hline 1 & Tudorenii & \multirow{4}{*}{ în ținutul Grecenilor } & \multirow{4}{*}{ spatarul Iordachi Roset } & \multirow{4}{*}{ comisul Iancul Balș } \\
\hline 2 & Petreceuca & & & \\
\hline 3 & Besăreca & & & \\
\hline 4 & Corcanii & & & \\
\hline 5 & Cimișăni & \multirow{4}{*}{ în ținutul Orheiului } & \multirow{4}{*}{$\begin{array}{l}\text { vechil postelnicul } \\
\text { Costachi Haret }\end{array}$} & \multirow{4}{*}{ comisul Costachi Sturza } \\
\hline 6 & Roșcanii & & & \\
\hline 7 & $\begin{array}{l}\text { părți din Cobusca de Sus } \\
\text { și de Gios ot Orhei }\end{array}$ & & & \\
\hline 8 & Petricanii ot Orheiu & & & \\
\hline 9 & $\begin{array}{l}\text { Vornicenii ot ținutul } \\
\text { Hotinului }\end{array}$ & \multirow{4}{*}{ în ținutul Sorocii } & \multirow{10}{*}{$\begin{array}{l}\text { vornicul Dimitrachi } \\
\text { Bogdan }\end{array}$} & \multirow{10}{*}{ spatarul Ioniță Bașotă } \\
\hline 10 & Ghizdita & & & \\
\hline 11 & Vale Țarigradului & & & \\
\hline 12 & Pustiul & & & \\
\hline 13 & Micoreni cu săliștile & \multirow{3}{*}{ în ținutul Orheiului } & & \\
\hline 14 & Țahnăuții cu săliștele & & & \\
\hline 15 & Holboca & & & \\
\hline 16 & $\begin{array}{l}\text { Șoltoae cu săliștile, în } \\
\text { ținutul Iașii }\end{array}$ & & & \\
\hline 17 & Tîrteștii & \multirow{2}{*}{ în ținutul Grecenilor } & & \\
\hline 18 & Coplenii & & & \\
\hline 19 & $\begin{array}{l}\text { din moșie Ialovăț, } 2 \\
\text { părți, în ținutul Orhei }\end{array}$ & & banul Ion Vârnav & spatarul Ioniță Başotă \\
\hline 20 & Popornița & \multirow{6}{*}{ în ținutul Eșii } & \multirow{6}{*}{$\begin{array}{l}\text { vistiernicul Grigoraș } \\
\text { Sturza }\end{array}$} & \multirow{6}{*}{ spatarul Ioniță Bașotă } \\
\hline 21 & $\begin{array}{l}\text { Nicorenii, ce să numesc } \\
\text { și Ochi Albu }\end{array}$ & & & \\
\hline 22 & Corcotenii cu săliștile & & & \\
\hline 23 & Răciula, cu săliștile & & & \\
\hline 24 & Aluniş, fără sat & & & \\
\hline 25 & Dondășănii, cu sat & & & \\
\hline 26 & $\begin{array}{l}\text { Mărceștii din ținutul } \\
\text { Orhei }\end{array}$ & & Mitropolia din Eși & spatarul Ioniță Başotă \\
\hline 27 & $\begin{array}{l}\text { Corneștii, ce să numești } \\
\text { și Cotelna, cu părțile, } \\
\text { din ținutul Lăpușna }\end{array}$ & & vornicul Dimitrii Ralet & $\begin{array}{l}\text { caminarul Zamfirachi } \\
\text { Rale }\end{array}$ \\
\hline 28 & Căpreștii & \multirow{2}{*}{ în ținutul Sorocăi } & spatarul Alexandru & Costandin Iofce vel \\
\hline 29 & Porcarii & & Mavrocordat & căpitan \\
\hline 30 & Dărcăuții & \multirow{3}{*}{ tij, ținutul Sorocii } & \multirow{3}{*}{ a Mitropoliei din Eși } & \multirow{3}{*}{$\begin{array}{l}\text { sardar Alexandru } \\
\text { Anastasiu }\end{array}$} \\
\hline 31 & Heleceu & & & \\
\hline 32 & Braicăul & & & \\
\hline 33 & Costuleni & \multirow{3}{*}{ din ținutul Iași } & \multirow{3}{*}{ tij a Mitropoliei din Iași } & \multirow{3}{*}{$\begin{array}{l}\text { tot sardarul Alexandru } \\
\text { Anastasiu }\end{array}$} \\
\hline 34 & Prisăcani & & & \\
\hline 35 & Hăuleștii & & & \\
\hline 36 & $\begin{array}{l}\text { Morțăștii cu săliștile, din } \\
\text { ținutul Lăpuşnii }\end{array}$ & & spatareasa Safta Bogda & $\begin{array}{l}\text { postelnicesei } \\
\text { Ghedeonovei }\end{array}$ \\
\hline 37 & Văsienii & \multirow[b]{4}{*}{ din ținutul Orheiului } & \multirow[b]{4}{*}{ spatarul Iancul Milcescu } & \multirow[b]{4}{*}{ spatarul Ioniță Bașotă } \\
\hline 38 & Manoileștii & & & \\
\hline 39 & Policenii & & & \\
\hline 40 & Comăneștii & & & \\
\hline
\end{tabular}




\begin{tabular}{|c|c|c|c|c|}
\hline 41 & Vișnăei ${ }^{26}$ & & & \\
\hline 42 & Bețănii & & & \\
\hline 43 & Mînzatu & & & \\
\hline 44 & $\begin{array}{l}\text { Volniceni, ce să numesc } \\
\text { și Potani, în ținutul } \\
\text { Hotinului }\end{array}$ & & șatrareasa Ralița Bosiiasa & colescului săcritar Ianov \\
\hline 45 & $\begin{array}{l}\text { o a } 4 \text { parti din moșie } \\
\text { Iurcenii, din ținutul } \\
\text { Orheiu }\end{array}$ & & & \\
\hline 46 & $\begin{array}{l}\text { Hulpeștii, din ținutul } \\
\text { Iași }\end{array}$ & & $\begin{array}{l}\text { paharniceasa Paraschiva } \\
\text { Iurașcova }^{27}\end{array}$ & fecioru ei, Costandin \\
\hline 47 & $\begin{array}{l}\text { Hotărniceni, cu toate } \\
\text { siliștile }\end{array}$ & & epitropii D. Moruz & comisul Iancul Balș \\
\hline 48 & Moleștii & & & \\
\hline 49 & $\begin{array}{l}\text { Drojdieștii, din ținutul } \\
\text { Sorocii }^{28}\end{array}$ & & aga Alecu Cantacuzino & Luca Estratiul \\
\hline 50 & $\begin{array}{l}\text { Ochinceștii, din ținutul } \\
\text { Sorocii }\end{array}$ & & $\begin{array}{l}\text { Rocsanda Roset } \\
\text { spatareasa }\end{array}$ & $\begin{array}{l}\text { postelnicul Iordachi } \\
\text { Frunzăti }\end{array}$ \\
\hline 51 & $\begin{array}{l}\text { Şărbăneștu }{ }^{29}, \text { din a } 4 \\
\text { parte o a } 16 \text { parti }\end{array}$ & & $\begin{array}{l}\text { preot Pantelimon } \\
\text { Petrachi }\end{array}$ & $\begin{array}{l}\text { lăcuitorilor din Bucovina, } \\
\text { Iordachi Tăut și lui }\end{array}$ \\
\hline 52 & $\begin{array}{l}\text { Fădcăuții cu o a } 3 \text { parte } \\
\text { din a } 3 \text { bătrîn. Aceste } \\
\text { părți sînt amîndoî în } \\
\text { ținutul Hotinului }\end{array}$ & & & Gheorghii Savinschii \\
\hline 53 & din Forosca a 32 părți & \multirow{3}{*}{ în ținutul Hotinului } & \multirow{3}{*}{$\begin{array}{l}\text { Gheorghii Alexandri și } \\
\text { Dumitru Luțchii }\end{array}$} & \multirow{3}{*}{$\begin{array}{l}\text { tot acestor de mai sus } \\
\text { arătați }\end{array}$} \\
\hline 54 & Șărbănețul & & & \\
\hline 55 & din Fătcăuți a 18 părți & & & \\
\hline 56 & $\begin{array}{l}\text { Modvaliche }{ }^{30}, \text { din } \\
\text { ținutul Orheiului }\end{array}$ & & $\begin{array}{l}\text { băniasa Catrina } \\
\text { Cozmuliasa }\end{array}$ & $\begin{array}{l}\text { caminaru Zamfirache } \\
\text { Rale }\end{array}$ \\
\hline 57 & $\begin{array}{l}\text { o a patra parte din } \\
\text { Hrușevăț, în ținutul } \\
\text { Hotinului }\end{array}$ & & $\begin{array}{l}\text { polcovniciasa Soltana } \\
\text { Tălpoai }\end{array}$ & lui Dumitru Sălcian \\
\hline 58 & Brătulenii & \multirow{7}{*}{ din ținutul Iașului } & \multirow{7}{*}{$\begin{array}{l}\text { pitarul Vasili Coroiu, cu } \\
\text { soru-sa, Iliana, după } \\
\text { diiată le-au dat }\end{array}$} & \multirow{7}{*}{$\begin{array}{l}\text { ficiorilor lui Vasili: lui } \\
\text { Gheorghii și fetilor, } \\
\text { Zmărandii și Profirii }\end{array}$} \\
\hline 59 & Morăștii & & & \\
\hline 60 & Negreștii & & & \\
\hline 61 & Horăștii & & & \\
\hline 62 & Marcăru $^{31}$ & & & \\
\hline 63 & Corneștii & & & \\
\hline 64 & Hotineștii & & & \\
\hline 65 & a 6 parte din Hădărăuți & \multirow{2}{*}{ în ținutul Hotinului } & \multirow{2}{*}{$\begin{array}{l}\text { stolnicul Grigori Tomița } \\
\text { și Costache Manole }\end{array}$} & \multirow{2}{*}{$\begin{array}{l}\text { sardarul Manolachi } \\
\text { Radul }\end{array}$} \\
\hline 66 & $\begin{array}{l}\text { giumătate din } \\
\text { Măndăcăuți }\end{array}$ & & & \\
\hline 67 & Miclăușăni & \multirow{2}{*}{ în ținutul Iaşi } & \multirow{2}{*}{ Ion Scorțăscu } & \multirow{2}{*}{ știab căpitan Stroici } \\
\hline 68 & giumătate de Trilești & & & \\
\hline 69 & $\begin{array}{l}\text { a patra parte din Ținești, } \\
\text { ținutul Hotinului }\end{array}$ & & Vasili Lână & lui Iordachi Morțun \\
\hline 70 & $\begin{array}{l}\text { a } 3 \text { parte din Dumeni, } \\
\text { ținutul Hotinului }\end{array}$ & & $\begin{array}{l}\text { păhărniceasa Nastasie } \\
\text { Stamate }\end{array}$ & paharnicul Toma Stamate \\
\hline 71 & $\begin{array}{l}\text { Meșănii, ot ținutul } \\
\text { Orheiului }\end{array}$ & & maior Dănca & tot lui Stamate \\
\hline
\end{tabular}

\footnotetext{
${ }^{26}$ Probabil: „Văsieni”.

${ }^{27}$ Lectură nesigură.

${ }^{28}$ Mai întîi scriitorul a scris: „Orheiului”, după care a corectat.

${ }^{29}$ Așa în original; probabil: „Șerbinți”.

${ }^{30}$ Așa în original; nu am regăsit numele satelor în listele de sate ale ținutului Orhei.

${ }^{31}$ Așa în original; poate, greșit, pentru: „Măcărești” (?).
} 


\begin{tabular}{|c|c|c|c|c|}
\hline 72 & $\begin{array}{l}\text { Stăuceni, ținutul } \\
\text { Hotinului }\end{array}$ & & banul Ioniță Prăjăscu & tot lui Stamate \\
\hline 73 & Criveștii & \multirow{17}{*}{ în ținutul Sorocii } & \multirow{17}{*}{ spatarul Alexandru Ghica } & \multirow{17}{*}{$\begin{array}{l}\text { postelnicul Alexandru } \\
\text { Ghica }\end{array}$} \\
\hline 74 & Horghineștii & & & \\
\hline 75 & Cărăpuşăni & & & \\
\hline 76 & Pepelenii & & & \\
\hline 77 & Visternicenii & & & \\
\hline 78 & Cotuleștii & & & \\
\hline 79 & Pogribeni & & & \\
\hline 80 & Băgrăneștii & & & \\
\hline 81 & Mărculeștii & & & \\
\hline 82 & Trepeteni & & & \\
\hline 83 & Floreștii & & & \\
\hline 84 & Buneștii & & & \\
\hline 85 & Săvirova & & & \\
\hline 86 & Albeștii & & & \\
\hline 87 & Coșărnița & & & \\
\hline 88 & Ciornița & & & \\
\hline 89 & Solonețul & & & \\
\hline 90 & $\begin{array}{l}\text { Ghinceștii, ot ținutul } \\
\text { Sorocii }\end{array}$ & & sardarul Isac Fedor & stolnicul Matei Râșcanu \\
\hline 91 & $\begin{array}{l}\text { Fundurelile, în ținutul } \\
\text { Iași }\end{array}$ & & $\begin{array}{l}\text { paharnicul Costandin } \\
\text { Miclescu }\end{array}$ & paharnicul Toma Stamate \\
\hline 92 & $\begin{array}{l}\text { T,ipirica, ot ținutul } \\
\text { Orheiului }\end{array}$ & & spatarul Dumitrachi Jora & tij lui Stamate \\
\hline 93 & Vlădeștii & \multirow{3}{*}{ în ținutul Grecenii } & \multirow{3}{*}{$\begin{array}{l}\text { spatarul Costandin } \\
\text { Sturza }\end{array}$} & \multirow{3}{*}{ spatarul Ioan Sturza } \\
\hline 94 & Brețcanii & & & \\
\hline 95 & $\begin{array}{l}\text { giumătate de Rujăneț, ce } \\
\text { să numește Bîrlădeni }\end{array}$ & & & \\
\hline 96 & Budeștii & \multirow{5}{*}{ în ținutul Orheiului } & \multirow{7}{*}{$\begin{array}{l}\text { vistiernicul Grigoraș } \\
\text { Sturza }\end{array}$} & \multirow{7}{*}{$\begin{array}{l}\text { vistiernicul Grigoraș } \\
\text { Sturza }\end{array}$} \\
\hline 97 & Dumăneștii & & & \\
\hline 98 & Chițcanii & & & \\
\hline 99 & Negurenii & & & \\
\hline 100 & o parte din Pupăzăni & & & \\
\hline 101 & $\begin{array}{l}\text { Tîrșițăni, ot ținutul } \\
\text { Sorocii }\end{array}$ & & & \\
\hline 102 & $\begin{array}{l}\text { Borzăștii, cu alte părți, în } \\
\text { ținutul Iași }\end{array}$ & & & \\
\hline 103 & $\begin{array}{l}488 \text { stînjăni din } \\
\text { Moruzăni }\end{array}$ & ținutul Orheiului & epitropii Catrini Stăvilă & tij lui Cazimir \\
\hline 104 & giumătati de Crucești & & & \\
\hline 105 & Costurenii ${ }^{32}$ & \multirow{5}{*}{ la ținutul Iaşi } & \multirow{5}{*}{$\begin{array}{l}\text { epitropii lui Toader Carp: } \\
\text { caminarul Ioan Carp şi } \\
\text { căpitanul Dumitru Carp }\end{array}$} & \multirow{5}{*}{$\begin{array}{l}\text { paharnicul Toma Stamate } \\
\text { și medelnicerul Andrieș }\end{array}$} \\
\hline 106 & din Bălăşăști, părți & & & \\
\hline 107 & din Bîncicani, părți & & & \\
\hline 108 & din Milești & & & \\
\hline 109 & din Cobăești & & & \\
\hline 110 & $\begin{array}{l}\text { giumătate de moșie } \\
\text { Cărpîța, din ținutul Iași }\end{array}$ & & caminarul Ioan Carp & $\begin{array}{l}\text { medelnicerul Mandachi } \\
\text { Andrieș }\end{array}$ \\
\hline 111 & Fedeștii & \multirow{2}{*}{ ținutul Iaşi } & \multirow{2}{*}{ vornicul Dimitrii Ralet } & sardarul Gheorghii \\
\hline 112 & o parte din Giulești & & & Leondari \\
\hline 113 & Telineștii & \multirow{2}{*}{ ținutul Orheiu } & călugărița Zamfira & caminarul Panaite \\
\hline 114 & $\begin{array}{l}\text { Dumeștii, ce să numești } \\
\text { și Ghermanca }\end{array}$ & & Scorțasca & Cazimir \\
\hline 115 & Vărticăuții & \multirow[b]{2}{*}{ ținutul Hotinului } & \multirow[b]{2}{*}{$\begin{array}{l}\text { sardarul Alexandru } \\
\text { Anastasiu }\end{array}$} & \multirow[b]{2}{*}{$\begin{array}{l}\text { tij, caminarului Panaite } \\
\text { Cazimir }\end{array}$} \\
\hline 116 & Dresîții ${ }^{33}$ & & & \\
\hline
\end{tabular}

\footnotetext{
${ }^{32}$ Sau „Costuleni”.

${ }^{33}$ Poate: „Drevcăuți”.
} 


\begin{tabular}{|c|c|c|c|c|}
\hline 117 & Solonețul & & & \\
\hline 118 & Mihălășăni & & & \\
\hline 119 & Vădenii & \multirow{2}{*}{$\begin{array}{l}\text { ținutul Orheiului sau } \\
\text { Lăpușna }\end{array}$} & \multirow{2}{*}{ tij sardarul Anastasiu } & \\
\hline 120 & Hudicenii & & & \\
\hline 121 & Mărteștii, părți & \multirow{4}{*}{$\begin{array}{l}\text { în ținutul Orheiului și a } \\
\text { Eșului }\end{array}$} & \multirow{4}{*}{ ban Toader Carp } & \multirow{4}{*}{$\begin{array}{l}\text { caminarul Panaite } \\
\text { Cazimir }\end{array}$} \\
\hline 122 & Grebleștii, părți & & & \\
\hline 123 & Ghireștii, părți & & & \\
\hline 124 & Mirceștii, părți & & & \\
\hline 125 & Vrăneștii & \multirow{2}{*}{ în ținutul Orheiului } & \multirow{2}{*}{ caminareasa Zoița Carp } & \multirow{2}{*}{ tot lui Cazimir } \\
\hline 126 & o parte din Onteni & & & \\
\hline 127 & o parti din Galbăna & & tij & \\
\hline 128 & Vătejăni & \multirow{2}{*}{ în ținutul Sorocii } & \multirow{2}{*}{$\begin{array}{l}\text { caminarul Costandin } \\
\text { Carp }\end{array}$} & \multirow{2}{*}{ tij lui Cazimir } \\
\hline 129 & Năpadova & & & \\
\hline 130 & $\begin{array}{l}\text { o parte din moșie } \\
\text { Chetroasa, ținutul } \\
\text { Orheiului }\end{array}$ & & tij & tij \\
\hline 131 & Levinții & \multirow{3}{*}{ ținutul Hotinului } & \multirow{3}{*}{ logofătul Iordachi Canta } & \multirow{3}{*}{ postelnicul Alecu Ghica } \\
\hline 132 & $\begin{array}{l}\text { giumătate de moşie } \\
\text { Balamutca }\end{array}$ & & & \\
\hline 133 & a 4 parte din Tribisăuți & & & \\
\hline 134 & Cărlăcău & \multirow{2}{*}{ ținutul Hotinului } & \multirow{2}{*}{ spatar Alexandru Ghica } & \multirow{2}{*}{ Vasili Roset } \\
\hline 135 & Romancăuți & & & \\
\hline 136 & $\begin{array}{l}\text { Salișca }^{34} \text {, în ținutul } \\
\text { Hotinului }\end{array}$ & & & \\
\hline 137 & a 3 parte din Dănceni & \multirow{3}{*}{ în ținutul Orheiului } & \multirow{3}{*}{$\begin{array}{l}\text { polcovnicul Panaite } \\
\text { Docan }\end{array}$} & \multirow{3}{*}{ Vasili Roset } \\
\hline 138 & a 3 parte din Dulițeni & & & \\
\hline 139 & a 3 parte din Ulmeni & & & \\
\hline 140 & Vărnăuții & \multirow{3}{*}{ ținutul Hotinului } & \multirow{5}{*}{ voniciasa Zoița Bălșoai } & \multirow{5}{*}{ stolnicul Matei Râșcanu } \\
\hline 141 & Vășcouţii & & & \\
\hline 142 & giumătate din Bîrlănești & & & \\
\hline 143 & $\begin{array}{l}\text { Izvoarăle și Lozăni, } \\
\text { ținutul Sorocăi }\end{array}$ & & & \\
\hline 144 & $\begin{array}{l}\text { Perisăcina, ținutul } \\
\text { Orheiului }\end{array}$ & & & \\
\hline 145 & Tătărășăni & \multirow{2}{*}{ ținutul Codrului } & \multirow{2}{*}{ sardareasa Ilinca Cantioai } & \\
\hline 146 & Bosîncenii & & & \\
\hline 147 & Șărpenii & tinutul Orheiului & snatarul Iordachi Ghica & Rucsandii Sturzoai \\
\hline 148 & Pugăcenii & ţınutur Orneruirus & spatarul Iordacni Gnica & Kucsanam sturzoal \\
\hline 149 & $\begin{array}{l}\text { Bîrnova și Cot(ul) } \\
\text { Sorocii, ținutul } \\
\text { Hotinului }\end{array}$ & & aga Alecu Ghica & $\begin{array}{l}\text { Neguțitorului din Odesa, } \\
\text { al 2-le ghildi, Coțovschii }\end{array}$ \\
\hline 150 & Măndăcăuții & tinutul Hotinului & sardarul Manolachi Radu & căpitanului Jancul Radul \\
\hline 151 & a 6 parte din Hădărăuți & & & \\
\hline 152 & $\begin{array}{l}\text { Vărtăporul }^{35} \text {, în ținutul } \\
\text { Hotinului }\end{array}$ & & $\begin{array}{l}\text { caminarul Costandin } \\
\text { Negre }\end{array}$ & $\begin{array}{l}\text { caminarul Panaite } \\
\text { Cazimir }\end{array}$ \\
\hline 153 & o parte din Cornești & tinutul Iasului & Marie, soție lui Toader & lui Iordachi Bantăs \\
\hline 154 & o parte din Coștoroh ${ }^{36}$ & ținutul rașuluı & Mărgărint & lu1 Lordachı Bantaș \\
\hline 155 & Tîrnova & tinutul Sorocii & Grioori Cugureni 37 & lui Ion Crâste \\
\hline 156 & giumătate de Briceva & (1) & Gingon c aguretin & Iut Hont Claste \\
\hline 157 & $\begin{array}{l}946 \text { stînjăni din Siliști, în } \\
\text { ținutul Iași }\end{array}$ & & $\begin{array}{l}\text { caminarul Anastasii } \\
\text { Scorțăscu }\end{array}$ & $\begin{array}{l}\text { caminarul Zamfirache } \\
\text { Rale }\end{array}$ \\
\hline 158 & o parti din Vărzărești & tinutul Orheiului & epitropii boierului & tiilui 7 amfirachi \\
\hline 159 & giumătati din Hoginești & ţınutus Orneruius & Conachi & c1) rui Lamnracni \\
\hline
\end{tabular}

\footnotetext{
${ }^{34}$ Probabil: „Seliște”.

${ }^{35}$ Probabil: „Vertep”.

${ }^{36}$ Așa în original.

${ }^{37}$ Probabil: „Ciuhureanu”.
} 


\begin{tabular}{|c|c|c|c|c|}
\hline 160 & Sirota, ținutul Orheiului & & banul Iordachi Drăghici & lui Zoe Dimitriu \\
\hline 161 & Bodeștii & & & \\
\hline 162 & $\begin{array}{l}\text { a } 3 \text { parte din Zhorna, } \\
\text { ținutul Sorocii }\end{array}$ & & tij, Drăghici & $\begin{array}{l}\text { clucerului Costachi } \\
\text { Bucșănescu }\end{array}$ \\
\hline 163 & Gîndeștii & \multirow{4}{*}{ ținutul Codrului } & \multirow{4}{*}{ vorniciasa Zoița Balș } & \multirow{4}{*}{ lui Vasili Crâste } \\
\hline 164 & Buciumeni & & & \\
\hline 165 & Cordeșîia & & & \\
\hline 166 & a 3 parte din Toceni & & & \\
\hline 167 & $\begin{array}{l}\text { Cosăuții, din ținutul } \\
\text { Sorocăi }\end{array}$ & & \multirow[t]{2}{*}{$\begin{array}{l}\text { spătăreasa Prihirițaa }^{38} \\
\text { Cantacozino }\end{array}$} & \multirow[t]{2}{*}{$\begin{array}{l}\text { comisul Alexandru } \\
\text { Panaite }\end{array}$} \\
\hline 168 & $\begin{array}{l}\text { Teșcureni, din ținutul } \\
\text { Iași }\end{array}$ & & & \\
\hline 169 & Tîrgu Leova & \multirow{9}{*}{$\begin{array}{l}\text { în ținutul Codrului i }{ }^{39} \text { a } \\
\text { Grecenilor. Deosăbit de } \\
\text { aceste sate și siliști ce sînt } \\
\text { pe locul cari să numești } \\
\text { Doî Ceasuri }\end{array}$} & \multirow{9}{*}{ logofătul Costachi Ghica } & \multirow{9}{*}{ spatarul Ioan Sturza } \\
\hline 170 & Măldărenii & & & \\
\hline 171 & Bebenii & & & \\
\hline 172 & Bujorul & & & \\
\hline 173 & Băzhanii $^{40}$ & & & \\
\hline 174 & Meșănii & & & \\
\hline 175 & Surducul & & & \\
\hline 176 & Horanevul & & & \\
\hline 177 & Mirceștii & & & \\
\hline 178 & Cepălăuții & \multirow{5}{*}{ în ținutul Hotinului } & \multirow{5}{*}{ tot Ghica } & \multirow{5}{*}{ tot Sturzii } \\
\hline 179 & Hancăuții & & & \\
\hline 180 & Anadolul & & & \\
\hline 181 & Vorhotinul $^{41}$ & & & \\
\hline 182 & Mihalcăuții & & & \\
\hline 183 & Bușăvca $^{42}$ & \multirow{2}{*}{ ținutul Orheiului } & \multirow{2}{*}{ logofătul Costachi Ghica } & \multirow{2}{*}{ spatarul Ioan Sturza } \\
\hline 184 & Ghidulenii & & & \\
\hline 185 & $\begin{array}{l}\text { Tășcureni, în ținutul } \\
\text { Iașului }\end{array}$ & & $\begin{array}{l}\text { comisul Alexandru } \\
\text { Panaite }\end{array}$ & lui Gheorghii Storianu \\
\hline 186 & $\begin{array}{l}\text { o parte din Tocsobeni, } \\
\text { ținutul Iașului }\end{array}$ & & $\begin{array}{l}\text { Cerchez ispravnic de } \\
\text { aprozi }\end{array}$ & lui Gheorghii Sorocianu \\
\hline 187 & o parte din Trifești & \multirow{7}{*}{ în ținutul Sorocăi } & \multirow{7}{*}{$\begin{array}{l}\text { pitarul Gheorghii } \\
\text { Sorocian }\end{array}$} & \multirow{7}{*}{$\begin{array}{l}\text { lui Grigori și Costandin, } \\
\text { Soroceni }\end{array}$} \\
\hline 188 & o parte din Mirceni & & & \\
\hline 189 & o parte din Cozmeni & & & \\
\hline 190 & o parte din Zăloboteni ${ }^{43}$ & & & \\
\hline 191 & o parte din Fore & & & \\
\hline 192 & o parte din Bocșilă & & & \\
\hline 193 & o parte din Marcăuți & & & \\
\hline 194 & $\begin{array}{l}946 \text { stînjăni din } \\
\text { Pojorăni, ținutul } \\
\text { Orheiului }\end{array}$ & & $\begin{array}{l}\text { logofeteasa Ilinca Păladi } \\
\text { și comisul Costandin } \\
\text { Bogdan }\end{array}$ & $\begin{array}{l}\text { lui Ioniță și Toader, } \\
\text { Surucenii }\end{array}$ \\
\hline 195 & $\begin{array}{l}\text { a } 3 \text { parte din Păşcăuți, ot } \\
\text { ținutul Iașului }\end{array}$ & & șătrarul Ștefan Stârce & $\begin{array}{l}\text { căpitanul Irimie } \\
\text { Ciuhurean }\end{array}$ \\
\hline 196 & Ezărenii & \multirow{4}{*}{ în ținutul Iașului } & \multirow{4}{*}{ ban Alexandru Beldiman } & \multirow{4}{*}{ lui Matei Panaite } \\
\hline 197 & Berheciul & & & \\
\hline 198 & Coretaneștii & & & \\
\hline 199 & cîteva părți din Roșcani & & & \\
\hline 200 & Sanja & \multirow{2}{*}{ ținutul Sorocăi } & \multirow{2}{*}{ Grigorii Başotă } & \multirow{2}{*}{ stolnicul Ion Bantăș } \\
\hline 201 & Cucueții & & & \\
\hline
\end{tabular}

\footnotetext{
${ }^{38}$ Așa în original, pentru: „Prohirița”.

${ }^{39}$ Slavonism: „si".

${ }^{40}$ Așa în original.

${ }^{41}$ Așa în original.

42 „Bușăuca”.

43 „Zăboloteni”.
} 


\begin{tabular}{|c|c|c|c|c|}
\hline 202 & Căzăneștii & \multirow{2}{*}{ ținutul Orheiului } & \multirow{2}{*}{$\begin{array}{l}\text { epitropii banului } \\
\text { Costachi Sturza }\end{array}$} & \multirow{2}{*}{ maiorului Șăinovici ${ }^{44}$} \\
\hline 203 & o parte din Cetilova & & & \\
\hline 204 & $\begin{array}{l}\text { Vărdeșăni, în ținutul } \\
\text { Codrului }^{45}\end{array}$ & & Petre Rosăt & lui Vasile Rosăt \\
\hline 205 & Țiganca & \multirow{2}{*}{ în ținutul Orheiului } & \multirow{2}{*}{ stolnicul Ion Costachi } & caminarul Panaite \\
\hline 206 & Negreleștii & & & Cazimir \\
\hline 207 & $\begin{array}{l}\text { Ocnița, din ținutul } \\
\text { Hotinului }\end{array}$ & & & \\
\hline 208 & $\begin{array}{l}\text { giumătate de Bălți din } \\
\text { ținutul Soroca }\end{array}$ & & comisul Costachi Sturza & caminarul Pruncu \\
\hline 209 & Chelmeștii & \multirow{4}{*}{ ținutul Hotin } & \multirow{4}{*}{$\begin{array}{l}\text { vistiernicul Iordache } \\
\text { Roset }\end{array}$} & \multirow{4}{*}{$\begin{array}{l}\text { caminarul Panaite } \\
\text { Cazimir }\end{array}$} \\
\hline 210 & Muşinețul & & & \\
\hline 211 & $\begin{array}{l}\text { o a } 10 \text { parte din } 24 \text { părți } \\
\text { din Cruhlic }\end{array}$ & & & \\
\hline 212 & o a 4 parte din Sîngereni & & & \\
\hline 213 & Vădenii & \multirow{2}{*}{ în ținutul Sorocii } & \multirow{7}{*}{ hatmanul Sandul Sturza } & \multirow{7}{*}{ lui Panaite Cazimir } \\
\hline 214 & Tăbărceni & & & \\
\hline 215 & Costănelu & \multirow{2}{*}{ ținutul Iașului } & & \\
\hline 216 & Zabulenii & & & \\
\hline 217 & Zăhăicani & \multirow{3}{*}{ ținutul Orheiului } & & \\
\hline 218 & Tîrzieni & & & \\
\hline 219 & $\begin{array}{l}\text { Braviceni, mai mult de } \\
\text { giumătate }\end{array}$ & & & \\
\hline 220 & $\begin{array}{l}\text { Nilipăuții, din ținutul } \\
\text { Hotinului }\end{array}$ & & ban Dumitru Beldiman & spatarul Ioan Sturza \\
\hline 221 & Cotujăni & \multirow{2}{*}{ ținutul Sorocii } & \multirow{2}{*}{$\begin{array}{l}\text { spatareasa Rucsanda } \\
\text { Roset }\end{array}$} & \multirow{2}{*}{ lui Gheorghii Dimitriu } \\
\hline 222 & Bejăica $^{46}$ & & & \\
\hline 223 & Verjîca $^{47}$ & \multirow{4}{*}{ în ținutul Hotinului } & \multirow{4}{*}{ caminarul Mihalachi } & \multirow{4}{*}{$\begin{array}{l}\text { caminarul Zamfirachi } \\
\text { Rale }\end{array}$} \\
\hline 224 & Bobena & & & \\
\hline 225 & Vălcinețu & & & \\
\hline 226 & $\begin{array}{l}300 \text { stînjăni din } \\
\text { Trășteni }{ }^{48} \text {, ot ținutul } \\
\text { Iașului }\end{array}$ & & & \\
\hline 227 & $\begin{array}{l}124 \text { stînjăni din Iazoviţi } \\
\text { și } 4 \text { stînjăni din } \\
\text { Tocsobeni }\end{array}$ & \multirow[t]{2}{*}{ ținutul Iaşi } & \multirow[t]{2}{*}{$\begin{array}{l}\text { Nastasie Ciorniiasa } \\
\text { Gheorghii Heciulă }^{49}\end{array}$} & \multirow[t]{2}{*}{$\begin{array}{l}\text { postelnicul Vasile Cujbă } \\
\text { tij lui Cujbă }\end{array}$} \\
\hline 228 & o parte din Onteni $^{50}$ & & & \\
\hline 229 & Bărbănăuții & \multirow{4}{*}{$\begin{array}{l}\text { cîte o parte dintr-însele ot } \\
\text { Hotin }\end{array}$} & \multirow{4}{*}{ Ion Ghițăscu } & \multirow{4}{*}{ lui Ioniță bănariul } \\
\hline 230 & Medveja & & & \\
\hline 231 & Cotăjini $^{51}$ & & & \\
\hline 232 & Hădărăuții & & & \\
\hline 233 & $\begin{array}{l}\text { O a patra parte din } 4 \\
\text { părți din moșie Stroeștii }\end{array}$ & \multirow[t]{2}{*}{ ținutul Hotinului } & \multirow[t]{2}{*}{$\begin{array}{l}\text { clucerul Ștefan și Ilii, } \\
\text { Holbănești }\end{array}$} & \multirow[t]{2}{*}{$\begin{array}{l}\text { supusului austriecesc } \\
\text { Costandin Morțun }\end{array}$} \\
\hline 234 & $\begin{array}{l}\text { O a patra parte din } \\
\text { Costuleni }\end{array}$ & & & \\
\hline 235 & $\begin{array}{l}\text { Putineștii, din ținutul } \\
\text { Sorocii }\end{array}$ & & spatarul Neculai Dimachi & lui Iordachi Donici \\
\hline
\end{tabular}

\footnotetext{
${ }^{44}$ Lectură nesigură.

${ }^{45}$ Urmează cuvintele: „către Răut”, tăiate.

${ }^{46}$ Lectură nesigură.

${ }^{47}$ Lectură nesigură.

48 „Trăisteni”.

${ }^{49}$ Lectură nesigură.

${ }^{50}$ Scris în continuare: „ținutul Eșului”, apoi tăiat.

${ }^{51}$ „Cotiujăni”.
} 


\begin{tabular}{|c|c|c|c|c|}
\hline 236 & $\begin{array}{l}\text { Voloșnicăul, din ținutul } \\
\text { Sorocii }\end{array}$ & & Zoița Cuzoai & $\begin{array}{l}\text { neguțătorului de Odesa, } \\
\text { al 2-le ghildi, Cuțovschii }\end{array}$ \\
\hline 237 & Negrinţii & \multirow{8}{*}{ ținutul Hotinului } & \multirow{8}{*}{ caminarul Ciure } & \multirow{8}{*}{ feciorului său } \\
\hline 238 & Horelcăuți & & & \\
\hline 239 & Criva & & & \\
\hline 240 & Nisfoaia & & & \\
\hline 241 & Şărcanii & & & \\
\hline 242 & giumătati de Zălina & & & \\
\hline 243 & $\begin{array}{l}\text { giumătati din } 16 \text { părți } \\
\text { din Zaluceni }\end{array}$ & & & \\
\hline 244 & $\begin{array}{l}3 \text { părți din } 4 \text { părți din } \\
\text { Pecicul }\end{array}$ & & & \\
\hline 245 & $\begin{array}{l}\text { o giumătati din } 112 \\
\text { parte din Costiceni }\end{array}$ & & & \\
\hline 246 & giumătati de Dumeni & \multirow{10}{*}{ ținutul Hotin } & \multirow{10}{*}{$\begin{array}{l}\text { Tudurachi Ciure, după } \\
\text { diiată }\end{array}$} & \multirow{10}{*}{ lui Costandin } \\
\hline 247 & giumătati de Şăndreni & & & \\
\hline 248 & giumătati de Mușineț & & & \\
\hline 249 & $\begin{array}{l}\text { a } 3 \text { parte din a } 4 \text { parte } \\
\text { din Cotela }\end{array}$ & & & \\
\hline 250 & $\begin{array}{l}\text { giumătate și o a } 6 \text { parte } \\
\text { din Solonețcu }\end{array}$ & & & \\
\hline 251 & $\begin{array}{l}\text { o a patra parte din a } 8 \\
\text { parte din Meleteuți }\end{array}$ & & & \\
\hline 252 & $\begin{array}{l}\text { o a } 3 \text { parte din } \\
\text { Colincăuți }\end{array}$ & & & \\
\hline 253 & o a 3 parte din Șișcăuți & & & \\
\hline 254 & o a 3 parte din Boșcani & & & \\
\hline 255 & o a 4 parte din Medveja & & & \\
\hline 256 & Bogdăneștii & \multirow{2}{*}{ în ținutul Iașului } & \multirow{3}{*}{ vornicul Grigori Ghica } & \multirow{3}{*}{$\begin{array}{l}\text { postelnicul Alexandru } \\
\text { Ghica }\end{array}$} \\
\hline 257 & Huhurez & & & \\
\hline 258 & Malinița ${ }^{52}$, Hotin & & & \\
\hline 259 & $\begin{array}{l}\text { Zarujăni, ținutul } \\
\text { Hotinului }\end{array}$ & & \multirow[t]{2}{*}{$\begin{array}{l}\text { a vornicului Neculai } \\
\text { Strătulat }\end{array}$} & \multirow[t]{2}{*}{ lui Dumitru Iani } \\
\hline 260 & $\begin{array}{l}\text { Cozăicu }^{53} \text {, ținutul } \\
\text { Orheiului }\end{array}$ & & & \\
\hline 261 & Duneștii & \multirow{2}{*}{ în ținutul Iaşului } & \multirow{2}{*}{ caminarul Andrei Başotă } & \multirow{2}{*}{$\begin{array}{l}\text { paharnicul Toma Stamate } \\
\text { și medelnicerul Andrieș }\end{array}$} \\
\hline 262 & o parte din Teșăni & & & \\
\hline 263 & Ohrince & \multirow{2}{*}{ ținutul Orheiului } & \multirow{3}{*}{ sărdar Grigori Codreanu } & \multirow{3}{*}{ caminar Panaite Cazimir } \\
\hline 264 & Drăicenii & & & \\
\hline 265 & $\begin{array}{l}\text { Iucanii }^{54}, \text { ținutul } \\
\text { Codrului }\end{array}$ & & & \\
\hline 266 & $\begin{array}{l}\text { a patra parte din } \\
\text { Paustova, ținutul } \\
\text { Hotinului }\end{array}$ & & clucerul Vasili Docan & lui Iordachi Bantăș \\
\hline 267 & $\begin{array}{l}\text { o parte din Albeștiot } \\
\text { Orheiu }\end{array}$ & & Iliana Bățoae & lui Stamati Bățu \\
\hline 268 & Bîrnova & \multirow{4}{*}{ ținutul Hotinului } & \multirow{4}{*}{ spatarul Grigori Balș } & \multirow{4}{*}{$\begin{array}{l}\text { caminarul Panaite } \\
\text { Cazimir }\end{array}$} \\
\hline 269 & Pernăuții & & & \\
\hline 270 & Beșenăuții & & & \\
\hline 271 & giumătati de Lopatinți & & & \\
\hline 272 & $\begin{array}{l}\text { Trăistei, ce-i zic și Plop, } \\
\text { ținutul Sorocii }\end{array}$ & & spatarul Petrachi Sturza & lui Spiridon Dimitriu \\
\hline 273 & Mălăeștii & \multirow[b]{2}{*}{ ținutul Orheiului } & \multirow[b]{2}{*}{ Iordachi Foti } & \multirow{2}{*}{$\begin{array}{l}\text { medelnicerul Ioniță } \\
\text { Nemișăscu }\end{array}$} \\
\hline 274 & Tudurcenii & & & \\
\hline
\end{tabular}




\begin{tabular}{|c|c|c|c|c|}
\hline 275 & Neceștui & & & \\
\hline 276 & $\begin{array}{l}\text { o parte din Cuizăuca, } \\
\text { ținutul Orheiului }\end{array}$ & & $\begin{array}{l}\text { comisul Alexandru } \\
\text { Hrisoverghi }\end{array}$ & tij, Nemişăscului \\
\hline 277 & Socii & \multirow{3}{*}{ ținutul Iaşii } & \multirow{3}{*}{$\begin{array}{l}\text { sărdar Costandin } \\
\text { Burghele }\end{array}$} & \multirow{3}{*}{$\begin{array}{l}\text { medelnicerul Gheorghii } \\
\text { Dimitriu }\end{array}$} \\
\hline 278 & a 6 parte din Bozieni & & & \\
\hline 279 & $\begin{array}{l}\text { a } 6 \text { parte din } \mathrm{Răd}(\mathrm{iu}) \\
\text { Mari }\end{array}$ & & & \\
\hline 280 & Aluru, ținutul Codrului & & spatarul Grigorii Cuza & lui Neculai Milu \\
\hline 281 & Taracauții & \multirow{2}{*}{ ținutul Iașii } & \multirow{2}{*}{ spatarul Costandin Roset } & \multirow{2}{*}{ spatarul Ioan Sturza } \\
\hline 282 & Măgura & & & \\
\hline 283 & Tilișăuca & \multirow{2}{*}{ ținutul Sorocii } & \multirow{2}{*}{ căminarul Vasili Balș } & paharnicul Stamati și \\
\hline 284 & Veșca & & & medelnicerul Andrieș \\
\hline 285 & $\begin{array}{l}\text { Borosănii, ținutul } \\
\text { Sorocii }\end{array}$ & & ban Ștefan Bașotă & tij, numiților mai sus \\
\hline 286 & Corneștii & \multirow{2}{*}{ ținutul Iașului } & stolniciasa Marie & \multirow{2}{*}{ neguțitoriului Capșa } \\
\hline 287 & o parte din Cozmeni & & Holbăniasa & \\
\hline 288 & $\begin{array}{l}\text { Vascăuții, ținutul } \\
\text { Orheiului }\end{array}$ & & Toader Silion & $\begin{array}{l}\text { paharnicul Stamate i lui } \\
\text { Andrieș }\end{array}$ \\
\hline 289 & $\begin{array}{l}\text { Cogîlniceni, ținutul } \\
\text { Orheiului }\end{array}$ & & $\begin{array}{l}\text { epitropii ficii lui } \\
\text { Manolachi Balș }\end{array}$ & $\begin{array}{l}\text { neguțitoriului Ion } \\
\text { Hărțăscu }\end{array}$ \\
\hline 290 & $\begin{array}{l}\text { o a patra parte din } \\
\text { Alcidar }\end{array}$ & \multirow[t]{2}{*}{ ținutul Sorocii } & \multirow[t]{2}{*}{$\begin{array}{l}\text { stolnicul Costandin } \\
\text { Manoli }\end{array}$} & \multirow[t]{2}{*}{$\begin{array}{l}\text { medelnicerul Manolachi } \\
\text { Andrieș }\end{array}$} \\
\hline 291 & $\begin{array}{l}\text { o a patra parte din } \\
\text { Leșciasa }\end{array}$ & & & \\
\hline 292 & Cocliia & \multirow{3}{*}{ ținutul Codrului } & \multirow{3}{*}{$\begin{array}{l}\text { paharnicul Alecu } \\
\text { Afenduli }\end{array}$} & \multirow{3}{*}{ sardarul Vartolomei } \\
\hline 293 & Giumătate de Răulele & & & \\
\hline 294 & $\begin{array}{l}\text { giumătate de Ruptura } \\
\text { Mare }\end{array}$ & & & \\
\hline 295 & Blîndenii & \multirow{2}{*}{ ținutul Orheiului } & & \\
\hline 296 & giumătate de Scurtești & & & \\
\hline 297 & o parte din Lămășăni & \multirow{4}{*}{ ținutul Hotinului } & \multirow{8}{*}{$\begin{array}{l}\text { Costandin Bantăș şi } \\
\text { spatareasa Marie } \\
\text { Costache }\end{array}$} & \multirow{8}{*}{$\begin{array}{l}\text { lui Iordachi Bantăș și } \\
\text { sptarului Ioan Sturza }\end{array}$} \\
\hline 298 & o parte din Dușăni & & & \\
\hline 299 & o parte din Pătrăuți & & & \\
\hline 300 & o parte din Căfieni & & & \\
\hline 301 & Brînzănii & \multirow{4}{*}{ ținutul Sorocii } & & \\
\hline 302 & Perienii & & & \\
\hline 303 & Climăuții & & & \\
\hline 304 & Horodiște & & & \\
\hline 305 & $\begin{array}{l}\text { Sinesul }^{55} \text {, ținutul } \\
\text { Hotinului }\end{array}$ & & $\begin{array}{l}\text { visitiernicul Sandul } \\
\text { Sturza }\end{array}$ & $\begin{array}{l}\text { caminarul Panaite } \\
\text { Cazimir }\end{array}$ \\
\hline 306 & $\begin{array}{l}\text { o a patra parte din } \\
\text { Mașcăuți, ținutul Soroca }\end{array}$ & & clucerul Tudurachi Ciure & surori-sa, Casandrii \\
\hline 307 & $\begin{array}{l}\text { Cioropcani, giumătate, } \\
\text { ținutul Iașului }\end{array}$ & & epitropii D. Muruz & lui Ilii Buzne \\
\hline 308 & giumătate de Cosăești & \multirow{2}{*}{ ținutul Hotinului } & \multirow{2}{*}{ ban Arghirii Cuza } & \multirow{2}{*}{ lui Iancu Dimitriu } \\
\hline 309 & Ghermăzănii & & & \\
\hline 310 & $\begin{array}{l}\text { Cupcinu, ținutul } \\
\text { Hotinului }\end{array}$ & & $\begin{array}{l}\text { ban Gheorghii și Toader } \\
\text { Buhuș }\end{array}$ & lui Costachi Popov \\
\hline 311 & Sărata, ținutul Orheiului & & epitropii D. Muruz & lui Vasili Iamandi \\
\hline 312 & Pravila & \multirow{2}{*}{ ținutul Sorocii } & \multirow{2}{*}{ tij, epitropii D. Muruz } & lui Cheorohii Meleli56 \\
\hline 313 & Vădurelile & & & luı Gheorghi1 Meleli \\
\hline 314 & $\begin{array}{l}\text { Lăncăuții, ținutul } \\
\text { Sorocii }\end{array}$ & & tij, epitropii D. Muruz & lui Vasili Pușcă \\
\hline 315 & $\begin{array}{l}\text { tîrg Telineștii, ținutul } \\
\text { Orheiului }\end{array}$ & & tij, epitropii & pitar Teodosii \\
\hline
\end{tabular}

\footnotetext{
${ }^{55}$ Așa în original.

${ }^{56}$ Probabil: „Meleghi”.
} 


\begin{tabular}{|c|c|c|c|c|}
\hline 316 & $\begin{array}{l}\text { Bogdăneștii, ținutul } \\
\text { Iașului }\end{array}$ & & sulgereasa Marie Năstasi & lui Panaite Cazimir \\
\hline 317 & $\begin{array}{l}\text { Crimenciuc, ținutul } \\
\text { Sorocii }\end{array}$ & & \multirow[t]{2}{*}{$\begin{array}{l}\text { stolnicul Iordachi } \\
\text { Murguleț }\end{array}$} & \multirow[t]{2}{*}{ feciorului său, Vasili } \\
\hline 318 & $\begin{array}{l}\text { o a } 3 \text { parte din giumătate } \\
\text { de Stroești, ţinutul } \\
\text { Hotinului }\end{array}$ & & & \\
\hline 319 & Unienii $^{57}$, ținutul Iașului & & Iliana Carage & comisul Alexandru Negre \\
\hline 320 & $\begin{array}{l}\text { Tintenii, ținutul } \\
\text { Grecenilor }\end{array}$ & & $\begin{array}{l}\text { sardăreasa Iliana } \\
\text { Cantacuzino }\end{array}$ & comisul Iancul Balș ${ }^{58}$ \\
\hline 321 & $\begin{array}{l}\text { o a } 3 \text { parte din } 5 \text { bătrîni } \\
\text { din Onteni, ținutul Iași }\end{array}$ & & Zamfira Cujboai & postelnicul Vasili Cujbă \\
\hline 322 & $\begin{array}{l}\text { Izbește, ținutul } \\
\text { Orheiului }\end{array}$ & & vornicul Costandin Balț & $\begin{array}{l}\text { vornicul Costandin } \\
\text { Păladi }\end{array}$ \\
\hline 323 & $\begin{array}{l}\text { giumătate de Paustova, } \\
\text { ținutul Hotinului }\end{array}$ & & clucerul Vasili Docan & tij lui Păladi \\
\hline 324 & Boșcana, giumătate & \multirow{4}{*}{ ținutul Hotinului } & \multirow{4}{*}{ sulgereasa Marie Brănoai } & \multirow{4}{*}{ paharnicul Toma Stamate } \\
\hline 325 & Vertepul, giumătate & & & \\
\hline 326 & Ringaciul, giumătate & & & \\
\hline 327 & Șălăuții, fără o a 4 parte & & & \\
\hline 328 & Cunice & \multirow{2}{*}{ ținutul Sorocii } & \multirow{2}{*}{ Safta Costinoai } & \multirow{2}{*}{ pitarul Teodosii } \\
\hline 329 & o parte din Hăsnășăni & & & \\
\hline 330 & $\begin{array}{l}\text { Corneștii, ținutul } \\
\text { Hotinului }\end{array}$ & & \multirow[t]{2}{*}{$\begin{array}{l}\text { hatmanul Răducanu } \\
\text { Roset }\end{array}$} & \multirow[t]{2}{*}{ comisul Iancul Balș } \\
\hline 331 & $\begin{array}{l}\text { giumătate de Frăsinești, } \\
\text { ținutul Iași }\end{array}$ & & & \\
\hline 332 & Drăgușăștii & \multirow{10}{*}{ ținutul Iaşii } & \multirow{10}{*}{ vornicul Alecu Balş } & \multirow{10}{*}{ comisul Iancul Balș } \\
\hline 333 & Zberoai & & & \\
\hline 334 & Piceștii & & & \\
\hline 335 & tîrg Pînzăreni & & & \\
\hline 336 & Pînzărenii Vechi & & & \\
\hline 337 & Sfrejănii & & & \\
\hline 338 & Ifrimeștiii & & & \\
\hline 339 & o parte din Bîlcurești & & & \\
\hline 340 & Vale Ranhului & & & \\
\hline 341 & Bălăniali"99 & & & \\
\hline 342 & $\begin{array}{l}\text { Pogoneștii, ținutul } \\
\text { Hotinului }\end{array}$ & & \multirow{4}{*}{ vistiernicul Alecu Balș } & \multirow{4}{*}{ comisul Iancul Balș } \\
\hline 343 & Corbul & \multirow{3}{*}{ ținutul Soroca } & & \\
\hline 344 & Ciornoleuca & & & \\
\hline 345 & Andrieșăni & & & \\
\hline 346 & $\begin{array}{l}\text { Vovătenii, cu alte părți, } \\
\text { ținutul Hotinului }\end{array}$ & & $\begin{array}{l}\text { medelnicerul Tănase } \\
\text { Feștilă }\end{array}$ & lui Vasile Crâste \\
\hline 347 & $\begin{array}{l}\text { o parte din Florenți, } \\
\text { ținutul Iași }\end{array}$ & & Ion Bosii & sulgerul Pascal Tudori \\
\hline 348 & $\begin{array}{l}\text { din Trifești i Frumoasa, } \\
\text { cîte o parte }\end{array}$ & \multirow[t]{2}{*}{ ținutul Grecenilor } & \multirow[t]{2}{*}{$\begin{array}{l}\text { spatarul Neculai } \\
\text { Hrisoverghi }\end{array}$} & \multirow[t]{2}{*}{ comisul Iancul Balș } \\
\hline 349 & $\begin{array}{l}\text { o a } 6 \text { parte din } \\
\text { Găunițăni }^{60}\end{array}$ & & & \\
\hline 350 & $\begin{array}{l}\text { giumătate de Hîrjăuți, } \\
\text { ținutul Hotinului }\end{array}$ & & $\begin{array}{l}\text { medelnicereasa Marie } \\
\text { Feștiloai }\end{array}$ & $\begin{array}{l}\text { caminarul Zamfirache } \\
\text { Rale }\end{array}$ \\
\hline 351 & giumătate de Cotiujăni & tinutul Hotinului & Darii iconomul & tit. sovednic Teodosiu \\
\hline
\end{tabular}

\footnotetext{
${ }^{57}$ Probabil: „Unghenii”.

${ }^{58}$ Nume scris pe loc șters.

59 „Bălănești”.

${ }^{60}$ Așa în original.
} 


\begin{tabular}{|c|c|c|c|c|}
\hline 352 & giumătate de Bosieni & & & \\
\hline 353 & Verejăni & \multirow{3}{*}{ ținutul Orheiului } & \multirow{3}{*}{ Marie Irimieva } & \multirow{3}{*}{ tij lui Teodosiu } \\
\hline 354 & Vărzăreștii & & & \\
\hline 355 & Bodurcenii & & & \\
\hline 356 & $\begin{array}{l}\text { Cerbiceni, giumătate, } \\
\text { ținutul Hotinului }\end{array}$ & & $\begin{array}{l}\text { paharniceasa Marie } \\
\text { Micliasca }\end{array}$ & tij lui Teodosiu \\
\hline 357 & $\begin{array}{l}\text { Șărăuții, ținutul } \\
\text { Hotinului }\end{array}$ & & \multirow[t]{2}{*}{$\begin{array}{l}\text { clucerul Dinu, Gheorghii } \\
\text { și Enachi, Negruțăști }\end{array}$} & \multirow[t]{2}{*}{ lui Manolachi Negruți } \\
\hline 358 & $\begin{array}{l}\text { Goteștii, ținutul } \\
\text { Grecenii }\end{array}$ & & & \\
\hline 359 & Tohatinu & \multirow{4}{*}{ ținutul Orheiului } & \multirow{15}{*}{ ban Petrachi Cazimir } & \multirow{15}{*}{ caminar Panaite Cazimir } \\
\hline 360 & Mihuțăni & & & \\
\hline 361 & Vadul lui Vodă & & & \\
\hline 362 & Boșcana & & & \\
\hline 363 & Stoicani, ținutul Sorocăi & & & \\
\hline 364 & Novosălița & \multirow{5}{*}{ ținutul Hotinului } & & \\
\hline 365 & Hropevna & & & \\
\hline 366 & o parte Deinăuți & & & \\
\hline 367 & giumătate de Rusăști & & & \\
\hline 368 & o a 4 parte de Nelipăuți & & & \\
\hline 369 & Săncăuții & & & \\
\hline 370 & o a 3 parte din Cotiujăni & & & \\
\hline 371 & Berlinții & & & \\
\hline 372 & giumătate de Gurmuzăni & & & \\
\hline 373 & $\begin{array}{l}2 \text { părți din o a } 5 \text { parti din } \\
\text { Nisloveni i din Copelova } \\
\text { și din Cotela }\end{array}$ & & & \\
\hline 374 & Dolinenii & \multirow{7}{*}{ ținutul Hotinului } & \multirow{7}{*}{ vornicul Toader Balș } & \multirow{7}{*}{ comisul Iancul Balș } \\
\hline 375 & Doljocu & & & \\
\hline 376 & o parte din Trebujăni & & & \\
\hline 377 & 10 părți din Cruhlic & & & \\
\hline 378 & o a 4 parte din Sîngereni & & & \\
\hline 379 & 12 părți din Bălcăuți & & & \\
\hline 380 & $\begin{array}{l}\text { o a patra parte din } \\
\text { Forosna }\end{array}$ & & & \\
\hline 381 & Silișăni & \multirow{5}{*}{ ținutul Hotinului } & \multirow{5}{*}{ vistiernicul Sandul Sturza } & \multirow{5}{*}{ comisul Iancul Balş } \\
\hline 382 & Roșcanii & & & \\
\hline 383 & $\begin{array}{l}\text { o parte din Cobusca de } \\
\text { Gios }\end{array}$ & & & \\
\hline 384 & o parte din Luica de Sus & & & \\
\hline 385 & o parte din Petreni & & & \\
\hline 386 & $\begin{array}{l}\text { a } 4 \text { parte din Drulești, ce } \\
\text { se numești și Săncăuți }\end{array}$ & & $\begin{array}{l}\text { caminarul Tudurachi } \\
\text { Ciure }\end{array}$ & Căsandrii Ciudinoai \\
\hline 387 & $\begin{array}{l}\text { Negreștii, ținutul } \\
\text { Orheiului }\end{array}$ & & vornicul Șărban Negel & lui Mihai Hermeziu \\
\hline
\end{tabular}

